\title{
Heavy Metals in Contaminated Soils: A Review of Sources, Chemistry, Risks and Best Available Strategies for Remediation
}

\author{
Raymond A. Wuana ${ }^{1}$ and Felix E. Okieimen ${ }^{2}$ \\ ${ }^{1}$ Analytical Environmental Chemistry Research Group, Department of Chemistry, Benue State University, \\ Makurdi 970001, Nigeria \\ ${ }^{2}$ Research Laboratory, GeoEnvironmental \& Climate Change Adaptation Research Centre, University of Benin, \\ Benin City 300283, Nigeria \\ Correspondence should be addressed to Raymond A. Wuana, rayway73@yahoo.com
}

Received 19 July 2011; Accepted 23 August 2011

Academic Editors: B. Montuelle and A. D. Steinman

Copyright ( $) 2011$ R. A. Wuana and F. E. Okieimen. This is an open access article distributed under the Creative Commons Attribution License, which permits unrestricted use, distribution, and reproduction in any medium, provided the original work is properly cited.

\begin{abstract}
Scattered literature is harnessed to critically review the possible sources, chemistry, potential biohazards and best available remedial strategies for a number of heavy metals (lead, chromium, arsenic, zinc, cadmium, copper, mercury and nickel) commonly found in contaminated soils. The principles, advantages and disadvantages of immobilization, soil washing and phytoremediation techniques which are frequently listed among the best demonstrated available technologies for cleaning up heavy metal contaminated sites are presented. Remediation of heavy metal contaminated soils is necessary to reduce the associated risks, make the land resource available for agricultural production, enhance food security and scale down land tenure problems arising from changes in the land use pattern.
\end{abstract}

\section{Introduction}

Soils may become contaminated by the accumulation of heavy metals and metalloids through emissions from the rapidly expanding industrial areas, mine tailings, disposal of high metal wastes, leaded gasoline and paints, land application of fertilizers, animal manures, sewage sludge, pesticides, wastewater irrigation, coal combustion residues, spillage of petrochemicals, and atmospheric deposition $[1,2]$. Heavy metals constitute an ill-defined group of inorganic chemical hazards, and those most commonly found at contaminated sites are lead $(\mathrm{Pb})$, chromium $(\mathrm{Cr})$, arsenic $(\mathrm{As})$, zinc $(\mathrm{Zn})$, cadmium $(\mathrm{Cd})$, copper $(\mathrm{Cu})$, mercury $(\mathrm{Hg})$, and nickel $(\mathrm{Ni})$ [3]. Soils are the major sink for heavy metals released into the environment by aforementioned anthropogenic activities and unlike organic contaminants which are oxidized to carbon (IV) oxide by microbial action, most metals do not undergo microbial or chemical degradation [4], and their total concentration in soils persists for a long time after their introduction [5]. Changes in their chemical forms (speciation) and bioavailability are, however, possible. The presence of toxic metals in soil can severely inhibit the biodegradation of organic contaminants [6]. Heavy metal contamination of soil may pose risks and hazards to humans and the ecosystem through: direct ingestion or contact with contaminated soil, the food chain (soil-plant-human or soil-plant-animalhuman), drinking of contaminated ground water, reduction in food quality (safety and marketability) via phytotoxicity, reduction in land usability for agricultural production causing food insecurity, and land tenure problems [7-9].

The adequate protection and restoration of soil ecosystems contaminated by heavy metals require their characterization and remediation. Contemporary legislation respecting environmental protection and public health, at both national and international levels, are based on data that characterize chemical properties of environmental phenomena, especially those that reside in our food chain [10]. While soil characterization would provide an insight into heavy metal speciation and bioavailability, attempt at remediation of heavy metal contaminated soils would entail knowledge of the source of contamination, basic chemistry, and environmental and associated health effects (risks) of these heavy 
metals. Risk assessment is an effective scientific tool which enables decision makers to manage sites so contaminated in a cost-effective manner while preserving public and ecosystem health [11].

Immobilization, soil washing, and phytoremediation techniques are frequently listed among the best demonstrated available technologies (BDATs) for remediation of heavy metal-contaminated sites [3]. In spite of their costeffectiveness and environment friendliness, field applications of these technologies have only been reported in developed countries. In most developing countries, these are yet to become commercially available technologies possibly due to the inadequate awareness of their inherent advantages and principles of operation. With greater awareness by the governments and the public of the implications of contaminated soils on human and animal health, there has been increasing interest amongst the scientific community in the development of technologies to remediate contaminated sites [12]. In developing countries with great population density and scarce funds available for environmental restoration, lowcost and ecologically sustainable remedial options are required to restore contaminated lands so as to reduce the associated risks, make the land resource available for agricultural production, enhance food security, and scale down land tenure problems.

In this paper, scattered literature is utilized to review the possible sources of contamination, basic chemistry, and the associated environmental and health risks of priority heavy metals ( $\mathrm{Pb}, \mathrm{Cr}$, As, $\mathrm{Zn}, \mathrm{Cd}, \mathrm{Cu}, \mathrm{Hg}$, and $\mathrm{Ni}$ ) which can provide insight into heavy metal speciation, bioavailability, and hence selection of appropriate remedial options. The principles, advantages, and disadvantages of immobilization, soil washing, and phytoremediation techniques as options for soil cleanup are also presented.

\section{Sources of Heavy Metals in Contaminated Soils}

Heavy metals occur naturally in the soil environment from the pedogenetic processes of weathering of parent materials at levels that are regarded as trace $\left(<1000 \mathrm{mg} \mathrm{kg}^{-1}\right)$ and rarely toxic $[10,13]$. Due to the disturbance and acceleration of nature's slowly occurring geochemical cycle of metals by man, most soils of rural and urban environments may accumulate one or more of the heavy metals above defined background values high enough to cause risks to human health, plants, animals, ecosystems, or other media [14]. The heavy metals essentially become contaminants in the soil environments because (i) their rates of generation via manmade cycles are more rapid relative to natural ones, (ii) they become transferred from mines to random environmental locations where higher potentials of direct exposure occur, (iii) the concentrations of the metals in discarded products are relatively high compared to those in the receiving environment, and (iv) the chemical form (species) in which a metal is found in the receiving environmental system may render it more bioavailable [14]. A simple mass balance of the heavy metals in the soil can be expressed as follows $[15,16]$ :

$M_{\mathrm{total}}=\left(M_{p}+M_{a}+M_{f}+M_{\mathrm{ag}}+M_{\mathrm{ow}}+M_{\mathrm{ip}}\right)-\left(M_{\mathrm{cr}}+M_{l}\right)$,

where " $M$ " is the heavy metal, " $p$ " is the parent material, " $a$ " is the atmospheric deposition, " $f$ " is the fertilizer sources, "ag" are the agrochemical sources, "ow" are the organic waste sources, "ip" are other inorganic pollutants, "cr" is crop removal, and " $l$ " is the losses by leaching, volatilization, and so forth. It is projected that the anthropogenic emission into the atmosphere, for several heavy metals, is one-to-three orders of magnitude higher than natural fluxes [17]. Heavy metals in the soil from anthropogenic sources tend to be more mobile, hence bioavailable than pedogenic, or lithogenic ones $[18,19]$. Metal-bearing solids at contaminated sites can originate from a wide variety of anthropogenic sources in the form of metal mine tailings, disposal of high metal wastes in improperly protected landfills, leaded gasoline and leadbased paints, land application of fertilizer, animal manures, biosolids (sewage sludge), compost, pesticides, coal combustion residues, petrochemicals, and atmospheric deposition $[1,2,20]$ are discussed hereunder.

2.1. Fertilizers. Historically, agriculture was the first major human influence on the soil [21]. To grow and complete the lifecycle, plants must acquire not only macronutrients $(\mathrm{N}, \mathrm{P}$, $\mathrm{K}, \mathrm{S}, \mathrm{Ca}$, and $\mathrm{Mg}$ ), but also essential micronutrients. Some soils are deficient in the heavy metals (such as $\mathrm{Co}, \mathrm{Cu}, \mathrm{Fe}, \mathrm{Mn}$, $\mathrm{Mo}, \mathrm{Ni}$, and $\mathrm{Zn}$ ) that are essential for healthy plant growth [22], and crops may be supplied with these as an addition to the soil or as a foliar spray. Cereal crops grown on $\mathrm{Cu}-$ deficient soils are occasionally treated with $\mathrm{Cu}$ as an addition to the soil, and Mn may similarly be supplied to cereal and root crops. Large quantities of fertilizers are regularly added to soils in intensive farming systems to provide adequate $\mathrm{N}$, $\mathrm{P}$, and $\mathrm{K}$ for crop growth. The compounds used to supply these elements contain trace amounts of heavy metals (e.g., $\mathrm{Cd}$ and $\mathrm{Pb}$ ) as impurities, which, after continued fertilizer, application may significantly increase their content in the soil [23]. Metals, such as $\mathrm{Cd}$ and $\mathrm{Pb}$, have no known physiological activity. Application of certain phosphatic fertilizers inadvertently adds $\mathrm{Cd}$ and other potentially toxic elements to the soil, including $\mathrm{F}, \mathrm{Hg}$, and $\mathrm{Pb}$ [24].

2.2. Pesticides. Several common pesticides used fairly extensively in agriculture and horticulture in the past contained substantial concentrations of metals. For instance in the recent past, about $10 \%$ of the chemicals have approved for use as insecticides and fungicides in UK were based on compounds which contain $\mathrm{Cu}, \mathrm{Hg}, \mathrm{Mn}, \mathrm{Pb}$, or $\mathrm{Zn}$. Examples of such pesticides are copper-containing fungicidal sprays such as Bordeaux mixture (copper sulphate) and copper oxychloride [23]. Lead arsenate was used in fruit orchards for many years to control some parasitic insects. Arseniccontaining compounds were also used extensively to control cattle ticks and to control pests in banana in New Zealand 
and Australia, timbers have been preserved with formulations of $\mathrm{Cu}, \mathrm{Cr}$, and As (CCA), and there are now many derelict sites where soil concentrations of these elements greatly exceed background concentrations. Such contamination has the potential to cause problems, particularly if sites are redeveloped for other agricultural or nonagricultural purposes. Compared with fertilizers, the use of such materials has been more localized, being restricted to particular sites or crops [8].

2.3. Biosolids and Manures. The application of numerous biosolids (e.g., livestock manures, composts, and municipal sewage sludge) to land inadvertently leads to the accumulation of heavy metals such as $\mathrm{As}, \mathrm{Cd}, \mathrm{Cr}, \mathrm{Cu}, \mathrm{Pb}, \mathrm{Hg}, \mathrm{Ni}, \mathrm{Se}$, $\mathrm{Mo}, \mathrm{Zn}, \mathrm{Tl}, \mathrm{Sb}$, and so forth, in the soil [20]. Certain animal wastes such as poultry, cattle, and pig manures produced in agriculture are commonly applied to crops and pastures either as solids or slurries [25]. Although most manures are seen as valuable fertilizers, in the pig and poultry industry, the $\mathrm{Cu}$ and $\mathrm{Zn}$ added to diets as growth promoters and As contained in poultry health products may also have the potential to cause metal contamination of the soil $[25,26]$. The manures produced from animals on such diets contain high concentrations of $\mathrm{As}, \mathrm{Cu}$, and $\mathrm{Zn}$ and, if repeatedly applied to restricted areas of land, can cause considerable buildup of these metals in the soil in the long run.

Biosolids (sewage sludge) are primarily organic solid products, produced by wastewater treatment processes that can be beneficially recycled [27]. Land application of biosolids materials is a common practice in many countries that allow the reuse of biosolids produced by urban populations [28]. The term sewage sludge is used in many references because of its wide recognition and its regulatory definition. However, the term biosolids is becoming more common as a replacement for sewage sludge because it is thought to reflect more accurately the beneficial characteristics inherent to sewage sludge [29]. It is estimated that in the United States, more than half of approximately 5.6 million dry tonnes of sewage sludge used or disposed of annually is land applied, and agricultural utilization of biosolids occurs in every region of the country. In the European community, over $30 \%$ of the sewage sludge is used as fertilizer in agriculture [29]. In Australia over 175000 tonnes of dry biosolids are produced each year by the major metropolitan authorities, and currently most biosolids applied to agricultural land are used in arable cropping situations where they can be incorporated into the soil [8].

There is also considerable interest in the potential for composting biosolids with other organic materials such as sawdust, straw, or garden waste. If this trend continues, there will be implications for metal contamination of soils. The potential of biosolids for contaminating soils with heavy metals has caused great concern about their application in agricultural practices [30]. Heavy metals most commonly found in biosolids are $\mathrm{Pb}, \mathrm{Ni}, \mathrm{Cd}, \mathrm{Cr}, \mathrm{Cu}$, and $\mathrm{Zn}$, and the metal concentrations are governed by the nature and the intensity of the industrial activity, as well as the type of process employed during the biosolids treatment [31]. Under certain conditions, metals added to soils in applications of biosolids can be leached downwards through the soil profile and can have the potential to contaminate groundwater [32]. Recent studies on some New Zealand soils treated with biosolids have shown increased concentrations of $\mathrm{Cd}, \mathrm{Ni}$, and $\mathrm{Zn}$ in drainage leachates $[33,34]$.

2.4. Wastewater. The application of municipal and industrial wastewater and related effluents to land dates back 400 years and now is a common practice in many parts of the world [35]. Worldwide, it is estimated that 20 million hectares of arable land are irrigated with waste water. In several Asian and African cities, studies suggest that agriculture based on wastewater irrigation accounts for 50 percent of the vegetable supply to urban areas [36]. Farmers generally are not bothered about environmental benefits or hazards and are primarily interested in maximizing their yields and profits. Although the metal concentrations in wastewater effluents are usually relatively low, long-term irrigation of land with such can eventually result in heavy metal accumulation in the soil.

2.5. Metal Mining and Milling Processes and Industrial Wastes. Mining and milling of metal ores coupled with industries have bequeathed many countries, the legacy of wide distribution of metal contaminants in soil. During mining, tailings (heavier and larger particles settled at the bottom of the flotation cell during mining) are directly discharged into natural depressions, including onsite wetlands resulting in elevated concentrations [37]. Extensive $\mathrm{Pb}$ and zinc $\mathrm{Zn}$ ore mining and smelting have resulted in contamination of soil that poses risk to human and ecological health. Many reclamation methods used for these sites are lengthy and expensive and may not restore soil productivity. Soil heavy metal environmental risk to humans is related to bioavailability. Assimilation pathways include the ingestion of plant material grown in (food chain), or the direct ingestion (oral bioavailability) of, contaminated soil [38].

Other materials are generated by a variety of industries such as textile, tanning, petrochemicals from accidental oil spills or utilization of petroleum-based products, pesticides, and pharmaceutical facilities and are highly variable in composition. Although some are disposed of on land, few have benefits to agriculture or forestry. In addition, many are potentially hazardous because of their contents of heavy metals $(\mathrm{Cr}, \mathrm{Pb}$, and $\mathrm{Zn})$ or toxic organic compounds and are seldom, if ever, applied to land. Others are very low in plant nutrients or have no soil conditioning properties [25].

2.6. Air-Borne Sources. Airborne sources of metals include stack or duct emissions of air, gas, or vapor streams, and fugitive emissions such as dust from storage areas or waste piles. Metals from airborne sources are generally released as particulates contained in the gas stream. Some metals such as $\mathrm{As}, \mathrm{Cd}$, and $\mathrm{Pb}$ can also volatilize during high-temperature processing. These metals will convert to oxides and condense as fine particulates unless a reducing atmosphere is maintained [39]. Stack emissions can be distributed over 
a wide area by natural air currents until dry and/or wet precipitation mechanisms remove them from the gas stream. Fugitive emissions are often distributed over a much smaller area because emissions are made near the ground. In general, contaminant concentrations are lower in fugitive emissions compared to stack emissions. The type and concentration of metals emitted from both types of sources will depend on site-specific conditions. All solid particles in smoke from fires and in other emissions from factory chimneys are eventually deposited on land or sea; most forms of fossil fuels contain some heavy metals and this is, therefore, a form of contamination which has been continuing on a large scale since the industrial revolution began. For example, very high concentration of $\mathrm{Cd}, \mathrm{Pb}$, and $\mathrm{Zn}$ has been found in plants and soils adjacent to smelting works. Another major source of soil contamination is the aerial emission of $\mathrm{Pb}$ from the combustion of petrol containing tetraethyl lead; this contributes substantially to the content of $\mathrm{Pb}$ in soils in urban areas and in those adjacent to major roads. $\mathrm{Zn}$ and $\mathrm{Cd}$ may also be added to soils adjacent to roads, the sources being tyres, and lubricant oils [40].

\section{Basic Soil Chemistry and Potential Risks of Heavy Metals}

The most common heavy metals found at contaminated sites, in order of abundance are $\mathrm{Pb}, \mathrm{Cr}, \mathrm{As}, \mathrm{Zn}, \mathrm{Cd}, \mathrm{Cu}$, and $\mathrm{Hg}$ [40]. Those metals are important since they are capable of decreasing crop production due to the risk of bioaccumulation and biomagnification in the food chain. There's also the risk of superficial and groundwater contamination. Knowledge of the basic chemistry, environmental, and associated health effects of these heavy metals is necessary in understanding their speciation, bioavailability, and remedial options. The fate and transport of a heavy metal in soil depends significantly on the chemical form and speciation of the metal. Once in the soil, heavy metals are adsorbed by initial fast reactions (minutes, hours), followed by slow adsorption reactions (days, years) and are, therefore, redistributed into different chemical forms with varying bioavailability, mobility, and toxicity $[41,42]$. This distribution is believed to be controlled by reactions of heavy metals in soils such as (i) mineral precipitation and dissolution, (ii) ion exchange, adsorption, and desorption, (iii) aqueous complexation, (iv) biological immobilization and mobilization, and (v) plant uptake [43].

3.1. Lead. Lead is a metal belonging to group IV and period 6 of the periodic table with atomic number 82, atomic mass 207.2 , density $11.4 \mathrm{~g} \mathrm{~cm}^{-3}$, melting point $327.4^{\circ} \mathrm{C}$, and boiling point $1725^{\circ} \mathrm{C}$. It is a naturally occurring, bluishgray metal usually found as a mineral combined with other elements, such as sulphur (i.e., $\mathrm{PbS}, \mathrm{PbSO}_{4}$ ), or oxygen $\left(\mathrm{PbCO}_{3}\right)$, and ranges from 10 to $30 \mathrm{mg} \mathrm{kg}^{-1}$ in the earth's crust [44]. Typical mean $\mathrm{Pb}$ concentration for surface soils worldwide averages $32 \mathrm{mg} \mathrm{kg}^{-1}$ and ranges from 10 to $67 \mathrm{mg} \mathrm{kg}^{-1}$ [10]. Lead ranks fifth behind $\mathrm{Fe}, \mathrm{Cu}, \mathrm{Al}$, and $\mathrm{Zn}$ in industrial production of metals. About half of the $\mathrm{Pb}$ used in the U.S. goes for the manufacture of $\mathrm{Pb}$ storage batteries. Other uses include solders, bearings, cable covers, ammunition, plumbing, pigments, and caulking. Metals commonly alloyed with $\mathrm{Pb}$ are antimony (in storage batteries), calcium (Ca) and tin $(\mathrm{Sn})$ (in maintenance-free storage batteries), silver (Ag) (for solder and anodes), strontium (Sr) and Sn (as anodes in electrowinning processes), tellurium (Te) (pipe and sheet in chemical installations and nuclear shielding), $\mathrm{Sn}$ (solders), and antimony (Sb), and Sn (sleeve bearings, printing, and high-detail castings) [45].

Ionic lead, $\mathrm{Pb}(\mathrm{II})$, lead oxides and hydroxides, and leadmetal oxyanion complexes are the general forms of $\mathrm{Pb}$ that are released into the soil, groundwater, and surface waters. The most stable forms of lead are $\mathrm{Pb}$ (II) and lead-hydroxy complexes. Lead(II) is the most common and reactive form of $\mathrm{Pb}$, forming mononuclear and polynuclear oxides and hydroxides [3]. The predominant insoluble $\mathrm{Pb}$ compounds are lead phosphates, lead carbonates (form when the $\mathrm{pH}$ is above 6), and lead (hydr)oxides [46]. Lead sulfide (PbS) is the most stable solid form within the soil matrix and forms under reducing conditions, when increased concentrations of sulfide are present. Under anaerobic conditions a volatile organolead (tetramethyl lead) can be formed due to microbial alkylation [3].

Lead(II) compounds are predominantly ionic (e.g., $\mathrm{Pb}^{2+}$ $\mathrm{SO}_{4}{ }^{2-}$ ), whereas $\mathrm{Pb}(\mathrm{IV})$ compounds tend to be covalent (e.g., tetraethyl lead, $\left.\mathrm{Pb}\left(\mathrm{C}_{2} \mathrm{H}_{5}\right)_{4}\right)$. Some $\mathrm{Pb}$ (IV) compounds, such as $\mathrm{PbO}_{2}$, are strong oxidants. Lead forms several basic salts, such as $\mathrm{Pb}(\mathrm{OH})_{2} \cdot 2 \mathrm{PbCO}_{3}$, which was once the most widely used white paint pigment and the source of considerable chronic lead poisoning to children who ate peeling white paint. Many compounds of $\mathrm{Pb}$ (II) and a few $\mathrm{Pb}$ (IV) compounds are useful. The two most common of these are lead dioxide and lead sulphate, which are participants in the reversible reaction that occurs during the charge and discharge of lead storage battery.

In addition to the inorganic compounds of lead, there are a number of organolead compounds such as tetraethyl lead. The toxicities and environmental effects of organolead compounds are particularly noteworthy because of the former widespread use and distribution of tetraethyllead as a gasoline additive. Although more than 1000 organolead compounds have been synthesized, those of commercial and toxicological importance are largely limited to the alkyl (methyl and ethyl) lead compounds and their salts (e.g., dimethyldiethyllead, trimethyllead chloride, and diethyllead dichloride).

Inhalation and ingestion are the two routes of exposure, and the effects from both are the same. $\mathrm{Pb}$ accumulates in the body organs (i.e., brain), which may lead to poisoning (plumbism) or even death. The gastrointestinal tract, kidneys, and central nervous system are also affected by the presence of lead. Children exposed to lead are at risk for impaired development, lower IQ, shortened attention span, hyperactivity, and mental deterioration, with children under the age of six being at a more substantial risk. Adults usually experience decreased reaction time, loss of memory, nausea, insomnia, anorexia, and weakness of the joints when exposed to lead [47]. Lead is not an essential element. It is well known 
to be toxic and its effects have been more extensively reviewed than the effects of other trace metals. Lead can cause serious injury to the brain, nervous system, red blood cells, and kidneys [48]. Exposure to lead can result in a wide range of biological effects depending on the level and duration of exposure. Various effects occur over a broad range of doses, with the developing young and infants being more sensitive than adults. Lead poisoning, which is so severe as to cause evident illness, is now very rare. Lead performs no known essential function in the human body, it can merely do harm after uptake from food, air, or water. Lead is a particularly dangerous chemical, as it can accumulate in individual organisms, but also in entire food chains.

The most serious source of exposure to soil lead is through direct ingestion (eating) of contaminated soil or dust. In general, plants do not absorb or accumulate lead. However, in soils testing high in lead, it is possible for some lead to be taken up. Studies have shown that lead does not readily accumulate in the fruiting parts of vegetable and fruit crops (e.g., corn, beans, squash, tomatoes, strawberries, and apples). Higher concentrations are more likely to be found in leafy vegetables (e.g., lettuce) and on the surface of root crops (e.g., carrots). Since plants do not take up large quantities of soil lead, the lead levels in soil considered safe for plants will be much higher than soil lead levels where eating of soil is a concern (pica). Generally, it has been considered safe to use garden produce grown in soils with total lead levels less than 300 ppm. The risk of lead poisoning through the food chain increases as the soil lead level rises above this concentration. Even at soil levels above 300 ppm, most of the risk is from lead contaminated soil or dust deposits on the plants rather than from uptake of lead by the plant [49].

3.2. Chromium. Chromium is a first-row $d$-block transition metal of group VIB in the periodic table with the following properties: atomic number 24 , atomic mass 52, density $7.19 \mathrm{~g} \mathrm{~cm}^{-3}$, melting point $1875^{\circ} \mathrm{C}$, and boiling point $2665^{\circ} \mathrm{C}$. It is one of the less common elements and does not occur naturally in elemental form, but only in compounds. Chromium is mined as a primary ore product in the form of the mineral chromite, $\mathrm{FeCr}_{2} \mathrm{O}_{4}$. Major sources of $\mathrm{Cr}$ contamination include releases from electroplating processes and the disposal of $\mathrm{Cr}$ containing wastes [39]. Chromi$\mathrm{um}(\mathrm{VI})$ is the form of Cr commonly found at contaminated sites. Chromium can also occur in the +III oxidation state, depending on $\mathrm{pH}$ and redox conditions. Chromium(VI) is the dominant form of $\mathrm{Cr}$ in shallow aquifers where aerobic conditions exist. Chromium(VI) can be reduced to $\mathrm{Cr}$ (III) by soil organic matter, $\mathrm{S}^{2-}$ and $\mathrm{Fe}^{2+}$ ions under anaerobic conditions often encountered in deeper groundwater. Major $\mathrm{Cr}$ (VI) species include chromate $\left(\mathrm{CrO}_{4}{ }^{2-}\right)$ and dichromate $\left(\mathrm{Cr}_{2} \mathrm{O}_{7}{ }^{2-}\right)$ which precipitate readily in the presence of metal cations (especially $\mathrm{Ba}^{2+}, \mathrm{Pb}^{2+}$, and $\mathrm{Ag}^{+}$). Chromate and dichromate also adsorb on soil surfaces, especially iron and aluminum oxides. Chromium(III) is the dominant form of $\mathrm{Cr}$ at low $\mathrm{pH}(<4) . \mathrm{Cr}^{3+}$ forms solution complexes with $\mathrm{NH}_{3}$, $\mathrm{OH}^{-}, \mathrm{Cl}^{-}, \mathrm{F}^{-}, \mathrm{CN}^{-}, \mathrm{SO}_{4}{ }^{2-}$, and soluble organic ligands. Chromium(VI) is the more toxic form of chromium and is also more mobile. Chromium(III) mobility is decreased by adsorption to clays and oxide minerals below $\mathrm{pH} 5$ and low solubility above $\mathrm{pH} 5$ due to the formation of $\mathrm{Cr}(\mathrm{OH})_{3}(\mathrm{~s})$ [50]. Chromium mobility depends on sorption characteristics of the soil, including clay content, iron oxide content, and the amount of organic matter present. Chromium can be transported by surface runoff to surface waters in its soluble or precipitated form. Soluble and un-adsorbed chromium complexes can leach from soil into groundwater. The leachability of $\mathrm{Cr}(\mathrm{VI})$ increases as soil $\mathrm{pH}$ increases. Most of Cr released into natural waters is particle associated, however, and is ultimately deposited into the sediment [39]. Chromium is associated with allergic dermatitis in humans [21].

3.3. Arsenic. Arsenic is a metalloid in group VA and period 4 of the periodic table that occurs in a wide variety of minerals, mainly as $\mathrm{As}_{2} \mathrm{O}_{3}$, and can be recovered from processing of ores containing mostly $\mathrm{Cu}, \mathrm{Pb}, \mathrm{Zn}, \mathrm{Ag}$ and $\mathrm{Au}$. It is also present in ashes from coal combustion. Arsenic has the following properties: atomic number 33, atomic mass 75 , density $5.72 \mathrm{~g} \mathrm{~cm}^{-3}$, melting point $817^{\circ} \mathrm{C}$, and boiling point $613^{\circ} \mathrm{C}$, and exhibits fairly complex chemistry and can be present in several oxidation states (-III, 0, III, V) [39]. In aerobic environments, As (V) is dominant, usually in the form of arsenate $\left(\mathrm{AsO}_{4}{ }^{3-}\right)$ in various protonation states: $\mathrm{H}_{3} \mathrm{AsO}_{4}, \mathrm{H}_{2} \mathrm{AsO}_{4}{ }^{-}, \mathrm{HAsO}_{4}{ }^{2-}$, and $\mathrm{AsO}_{4}{ }^{3-}$. Arsenate and other anionic forms of arsenic behave as chelates and can precipitate when metal cations are present [51]. Metal arsenate complexes are stable only under certain conditions. Arsenic (V) can also coprecipitate with or adsorb onto iron oxyhydroxides under acidic and moderately reducing conditions. Coprecipitates are immobile under these conditions, but arsenic mobility increases as $\mathrm{pH}$ increases [39]. Under reducing conditions As(III) dominates, existing as arsenite $\left(\mathrm{AsO}_{3}{ }^{3-}\right)$, and its protonated forms $\mathrm{H}_{3} \mathrm{AsO}_{3}, \mathrm{H}_{2} \mathrm{AsO}_{3}{ }^{-}$, and $\mathrm{HAsO}_{3}{ }^{2-}$. Arsenite can adsorb or coprecipitate with metal sulfides and has a high affinity for other sulfur compounds. Elemental arsenic and arsine, $\mathrm{AsH}_{3}$, may be present under extreme reducing conditions. Biotransformation (via methylation) of arsenic creates methylated derivatives of arsine, such as dimethyl arsine $\mathrm{HAs}\left(\mathrm{CH}_{3}\right)_{2}$ and trimethylarsine $\mathrm{As}\left(\mathrm{CH}_{3}\right)_{3}$ which are highly volatile. Since arsenic is often present in anionic form, it does not form complexes with simple anions such as $\mathrm{Cl}^{-}$and $\mathrm{SO}_{4}{ }^{2-}$. Arsenic speciation also includes organometallic forms such as methylarsinic acid $\left(\mathrm{CH}_{3}\right) \mathrm{AsO}_{2} \mathrm{H}_{2}$ and dimethylarsinic acid $\left(\mathrm{CH}_{3}\right)_{2} \mathrm{AsO}_{2} \mathrm{H}$. Many As compounds adsorb strongly to soils and are therefore transported only over short distances in groundwater and surface water. Arsenic is associated with skin damage, increased risk of cancer, and problems with circulatory system [21].

3.4. Zinc. Zinc is a transition metal with the following characteristics: period 4, group IIB, atomic number 30, atomic mass 65.4 , density $7.14 \mathrm{~g} \mathrm{~cm}^{-3}$, melting point $419.5^{\circ} \mathrm{C}$, and boiling point $906^{\circ} \mathrm{C}$. Zinc occurs naturally in soil (about $70 \mathrm{mg} \mathrm{kg}^{-1}$ in crustal rocks) [52], but $\mathrm{Zn}$ concentrations are 
rising unnaturally, due to anthropogenic additions. Most $\mathrm{Zn}$ is added during industrial activities, such as mining, coal, and waste combustion and steel processing. Many foodstuffs contain certain concentrations of $\mathrm{Zn}$. Drinking water also contains certain amounts of $\mathrm{Zn}$, which may be higher when it is stored in metal tanks. Industrial sources or toxic waste sites may cause the concentrations of $\mathrm{Zn}$ in drinking water to reach levels that can cause health problems. Zinc is a trace element that is essential for human health. Zinc shortages can cause birth defects. The world's $\mathrm{Zn}$ production is still on the rise which means that more and more $\mathrm{Zn}$ ends up in the environment. Water is polluted with $\mathrm{Zn}$, due to the presence of large quantities present in the wastewater of industrial plants. A consequence is that $\mathrm{Zn}$ polluted sludge is continually being deposited by rivers on their banks. Zinc may also increase the acidity of waters. Some fish can accumulate $\mathrm{Zn}$ in their bodies, when they live in $\mathrm{Zn}$-contaminated waterways. When $\mathrm{Zn}$ enters the bodies of these fish, it is able to biomagnify up the food chain. Water-soluble zinc that is located in soils can contaminate groundwater. Plants often have a $\mathrm{Zn}$ uptake that their systems cannot handle, due to the accumulation of $\mathrm{Zn}$ in soils. Finally, $\mathrm{Zn}$ can interrupt the activity in soils, as it negatively influences the activity of microorganisms and earthworms, thus retarding the breakdown of organic matter [53].

3.5. Cadmium. Cadmium is located at the end of the second row of transition elements with atomic number 48 , atomic weight 112.4 , density $8.65 \mathrm{~g} \mathrm{~cm}^{-3}$, melting point $320.9^{\circ} \mathrm{C}$, and boiling point $765^{\circ} \mathrm{C}$. Together with $\mathrm{Hg}$ and $\mathrm{Pb}, \mathrm{Cd}$ is one of the big three heavy metal poisons and is not known for any essential biological function. In its compounds, $\mathrm{Cd}$ occurs as the divalent $\mathrm{Cd}(\mathrm{II})$ ion. Cadmium is directly below $\mathrm{Zn}$ in the periodic table and has a chemical similarity to that of $\mathrm{Zn}$, an essential micronutrient for plants and animals. This may account in part for Cd's toxicity; because $\mathrm{Zn}$ being an essential trace element, its substitution by $\mathrm{Cd}$ may cause the malfunctioning of metabolic processes [54].

The most significant use of $\mathrm{Cd}$ is in $\mathrm{Ni} / \mathrm{Cd}$ batteries, as rechargeable or secondary power sources exhibiting high output, long life, low maintenance, and high tolerance to physical and electrical stress. Cadmium coatings provide good corrosion resistance coating to vessels and other vehicles, particularly in high-stress environments such as marine and aerospace. Other uses of cadmium are as pigments, stabilizers for polyvinyl chloride (PVC), in alloys and electronic compounds. Cadmium is also present as an impurity in several products, including phosphate fertilizers, detergents and refined petroleum products. In addition, acid rain and the resulting acidification of soils and surface waters have increased the geochemical mobility of $\mathrm{Cd}$, and as a result its surface-water concentrations tend to increase as lake water $\mathrm{pH}$ decreases [54]. Cadmium is produced as an inevitable byproduct of $\mathrm{Zn}$ and occasionally lead refining. The application of agricultural inputs such as fertilizers, pesticides, and biosolids (sewage sludge), the disposal of industrial wastes or the deposition of atmospheric contaminants increases the total concentration of $\mathrm{Cd}$ in soils, and the bioavailability of this $\mathrm{Cd}$ determines whether plant Cd uptake occurs to a significant degree [28]. Cadmium is very biopersistent but has few toxicological properties and, once absorbed by an organism, remains resident for many years.

Since the 1970s, there has been sustained interest in possible exposure of humans to $\mathrm{Cd}$ through their food chain, for example, through the consumption of certain species of shellfish or vegetables. Concern regarding this latter route (agricultural crops) led to research on the possible consequences of applying sewage sludge (Cd-rich biosolids) to soils used for crops meant for human consumption, or of using cadmium-enriched phosphate fertilizer [54]. This research has led to the stipulation of highest permissible concentrations for a number of food crops [8].

Cadmium in the body is known to affect several enzymes. It is believed that the renal damage that results in proteinuria is the result of $\mathrm{Cd}$ adversely affecting enzymes responsible for reabsorption of proteins in kidney tubules. Cadmium also reduces the activity of delta-aminolevulinic acid synthetase, arylsulfatase, alcohol dehydrogenase, and lipoamide dehydrogenase, whereas it enhances the activity of deltaaminolevulinic acid dehydratase, pyruvate dehydrogenase, and pyruvate decarboxylase [45]. The most spectacular and publicized occurrence of cadmium poisoning resulted from dietary intake of cadmium by people in the Jintsu River Valley, near Fuchu, Japan. The victims were afflicted by itai itai disease, which means ouch, ouch in Japanese. The symptoms are the result of painful osteomalacia (bone disease) combined with kidney malfunction. Cadmium poisoning in the Jintsu River Valley was attributed to irrigated rice contaminated from an upstream mine producing $\mathrm{Pb}, \mathrm{Zn}$, and $\mathrm{Cd}$. The major threat to human health is chronic accumulation in the kidneys leading to kidney dysfunction. Food intake and tobacco smoking are the main routes by which Cd enters the body [45].

3.6. Copper. Copper is a transition metal which belongs to period 4 and group IB of the periodic table with atomic number 29, atomic weight 63.5 , density $8.96 \mathrm{~g} \mathrm{~cm}^{-3}$, melting point $1083^{\circ} \mathrm{C}$ and boiling point $2595^{\circ} \mathrm{C}$. The metal's average density and concentrations in crustal rocks are $8.1 \times$ $10^{3} \mathrm{~kg} \mathrm{~m}^{-3}$ and $55 \mathrm{mg} \mathrm{kg}^{-1}$, respectively [52].

Copper is the third most used metal in the world [55]. Copper is an essential micronutrient required in the growth of both plants and animals. In humans, it helps in the production of blood haemoglobin. In plants, $\mathrm{Cu}$ is especially important in seed production, disease resistance, and regulation of water. Copper is indeed essential, but in high doses it can cause anaemia, liver and kidney damage, and stomach and intestinal irritation. Copper normally occurs in drinking water from $\mathrm{Cu}$ pipes, as well as from additives designed to control algal growth. While Cu's interaction with the environment is complex, research shows that most $\mathrm{Cu}$ introduced into the environment is, or rapidly becomes, stable and results in a form which does not pose a risk to the environment. In fact, unlike some man-made materials, $\mathrm{Cu}$ is not magnified in the body or bioaccumulated in the food chain. In the soil, $\mathrm{Cu}$ strongly complexes to the organic 
implying that only a small fraction of copper will be found in solution as ionic copper, $\mathrm{Cu}(\mathrm{II})$. The solubility of $\mathrm{Cu}$ is drastically increased at pH 5.5 [56], which is rather close to the ideal farmland $\mathrm{pH}$ of 6.0-6.5 [57].

Copper and $\mathrm{Zn}$ are two important essential elements for plants, microorganisms, animals, and humans. The connection between soil and water contamination and metal uptake by plants is determined by many chemical and physical soil factors as well as the physiological properties of the crops. Soils contaminated with trace metals may pose both direct and indirect threats: direct, through negative effects of metals on crop growth and yield, and indirect, by entering the human food chain with a potentially negative impact on human health. Even a reduction of crop yield by a few percent could lead to a significant long-term loss in production and income. Some food importers are now specifying acceptable maximum contents of metals in food, which might limit the possibility for the farmers to export their contaminated crops [36].

3.7. Mercury. Mercury belongs to same group of the periodic table with $\mathrm{Zn}$ and $\mathrm{Cd}$. It is the only liquid metal at stp. It has atomic number 80 , atomic weight 200.6 , density $13.6 \mathrm{~g} \mathrm{~cm}^{-3}$, melting point $-13.6^{\circ} \mathrm{C}$, and boiling point $357^{\circ} \mathrm{C}$ and is usually recovered as a byproduct of ore processing [39]. Release of $\mathrm{Hg}$ from coal combustion is a major source of $\mathrm{Hg}$ contamination. Releases from manometers at pressuremeasuring stations along gas/oil pipelines also contribute to $\mathrm{Hg}$ contamination. After release to the environment, $\mathrm{Hg}$ usually exists in mercuric $\left(\mathrm{Hg}^{2+}\right)$, mercurous $\left(\mathrm{Hg}_{2}{ }^{2+}\right)$, elemental $\left(\mathrm{Hg}^{\circ}\right)$, or alkylated form (methyl/ethyl mercury). The redox potential and $\mathrm{pH}$ of the system determine the stable forms of $\mathrm{Hg}$ that will be present. Mercurous and mercuric mercury are more stable under oxidizing conditions. When mildly reducing conditions exist, organic or inorganic $\mathrm{Hg}$ may be reduced to elemental $\mathrm{Hg}$, which may then be converted to alkylated forms by biotic or abiotic processes. Mercury is most toxic in its alkylated forms which are soluble in water and volatile in air [39]. Mercury(II) forms strong complexes with a variety of both inorganic and organic ligands, making it very soluble in oxidized aquatic systems [51]. Sorption to soils, sediments, and humic materials is an important mechanism for the removal of $\mathrm{Hg}$ from solution. Sorption is $\mathrm{pH}$ dependent and increases as $\mathrm{pH}$ increases. Mercury may also be removed from solution by coprecipitation with sulphides. Under anaerobic conditions, both organic and inorganic forms of $\mathrm{Hg}$ may be converted to alkylated forms by microbial activity, such as by sulfurreducing bacteria. Elemental mercury may also be formed under anaerobic conditions by demethylation of methyl mercury, or by reduction of $\mathrm{Hg}(\mathrm{II})$. Acidic conditions ( $\mathrm{pH}$ $<4)$ also favor the formation of methyl mercury, whereas higher $\mathrm{pH}$ values favor precipitation of $\mathrm{HgS}(\mathrm{s})$ [39]. Mercury is associated with kidney damage [21].

3.8. Nickel. Nickel is a transition element with atomic number 28 and atomic weight 58.69. In low $\mathrm{pH}$ regions, the metal exists in the form of the nickelous ion, $\mathrm{Ni}(\mathrm{II})$. In neutral to slightly alkaline solutions, it precipitates as nickelous hydroxide, $\mathrm{Ni}(\mathrm{OH})_{2}$, which is a stable compound. This precipitate readily dissolves in acid solutions forming $\mathrm{Ni}$ (III) and in very alkaline conditions; it forms nickelite ion, $\mathrm{HNiO}_{2}$, that is soluble in water. In very oxidizing and alkaline conditions, nickel exists in form of the stable nickelo-nickelic oxide, $\mathrm{Ni}_{3} \mathrm{O}_{4}$, that is soluble in acid solutions. Other nickel oxides such as nickelic oxide, $\mathrm{Ni}_{2} \mathrm{O}_{3}$, and nickel peroxide, $\mathrm{NiO}_{2}$, are unstable in alkaline solutions and decompose by giving off oxygen. In acidic regions, however, these solids dissolve producing $\mathrm{Ni}^{2+}$ [58].

Nickel is an element that occurs in the environment only at very low levels and is essential in small doses, but it can be dangerous when the maximum tolerable amounts are exceeded. This can cause various kinds of cancer on different sites within the bodies of animals, mainly of those that live near refineries. The most common application of $\mathrm{Ni}$ is an ingredient of steel and other metal products. The major sources of nickel contamination in the soil are metal plating industries, combustion of fossil fuels, and nickel mining and electroplating [59]. It is released into the air by power plants and trash incinerators and settles to the ground after undergoing precipitation reactions. It usually takes a long time for nickel to be removed from air. Nickel can also end up in surface water when it is a part of wastewater streams. The larger part of all $\mathrm{Ni}$ compounds that are released to the environment will adsorb to sediment or soil particles and become immobile as a result. In acidic soils, however, $\mathrm{Ni}$ becomes more mobile and often leaches down to the adjacent groundwater. Microorganisms can also suffer from growth decline due to the presence of $\mathrm{Ni}$, but they usually develop resistance to Ni after a while. Nickel is not known to accumulate in plants or animals and as a result $\mathrm{Ni}$ has not been found to biomagnify up the food chain. For animals $\mathrm{Ni}$ is an essential foodstuff in small amounts. The primary source of mercury is the sulphide ore cinnabar.

\section{Soil Concentration Ranges and Regulatory Guidelines for Some Heavy Metals}

The specific type of metal contamination found in a contaminated soil is directly related to the operation that occurred at the site. The range of contaminant concentrations and the physical and chemical forms of contaminants will also depend on activities and disposal patterns for contaminated wastes on the site. Other factors that may influence the form, concentration, and distribution of metal contaminants include soil and ground-water chemistry and local transport mechanisms [3].

Soils may contain metals in the solid, gaseous, or liquid phases, and this may complicate analysis and interpretation of reported results. For example, the most common method for determining the concentration of metals contaminants in soil is via total elemental analysis (USEPA Method 3050). The level of metal contamination determined by this method is expressed as mg metal $\mathrm{kg}^{-1}$ soil. This analysis does not specify requirements for the moisture content of the soil and may therefore include soil water. This measurement may also 
be reported on a dry soil basis. The level of contamination may also be reported as leachable metals as determined by leach tests, such as the toxicity characteristic leaching procedure (TCLP) (USEPA Method 1311) or the synthetic precipitation-leaching procedure, or SPLP test (USEPA Method 1312). These procedures measure the concentration of metals in leachate from soil contacted with an acetic acid solution (TCLP) [60] or a dilute solution of sulfuric and nitric acid (SPLP). In this case, metal contamination is expressed in $\mathrm{mgL}^{-1}$ of the leachable metal. Other types of leaching tests have been proposed including sequential extraction procedures $[61,62]$ and extraction of acid volatile sulfide [63]. Sequential procedures contact the solid with a series of extractant solutions that are designed to dissolve different fractions of the associated metal. These tests may provide insight into the different forms of metal contamination present. Contaminant concentrations can be measured directly in metals-contaminated water. These concentrations are most commonly expressed as total dissolved metals in mass concentrations $\left(\mathrm{mg} \mathrm{L}^{-1}\right.$ or $\left.\mathrm{gL}^{-1}\right)$ or in molar concentrations $\left(\mathrm{mol} \mathrm{L}^{-1}\right)$. In dilute solutions, a $\mathrm{mg} \mathrm{L}^{-1}$ is equivalent to one part per million (ppm), and a $\mathrm{gL}^{-1}$ is equivalent to one part per billion ( $\mathrm{ppb}$ ).

Riley et al. [64] and NJDEP [65] have reported soil concentration ranges and regulatory guidelines for some heavy metals (Table 1). In Nigeria, in the interim period, whilst suitable parameters are being developed, the Department of Petroleum Resources [60] has recommended guidelines on remediation of contaminated land based on two parameters intervention values and target values (Table 2).

The intervention values indicate the quality for which the functionality of soil for human, animal, and plant life are, or threatened with being seriously impaired. Concentrations in excess of the intervention values correspond to serious contamination. Target values indicate the soil quality required for sustainability or expressed in terms of remedial policy, the soil quality required for the full restoration of the soil's functionality for human, animal, and plant life. The target values therefore indicate the soil quality levels ultimately aimed at.

\section{Remediation of Heavy Metal-Contaminated Soils}

The overall objective of any soil remediation approach is to create a final solution that is protective of human health and the environment [66]. Remediation is generally subject to an array of regulatory requirements and can also be based on assessments of human health and ecological risks where no legislated standards exist or where standards are advisory. The regulatory authorities will normally accept remediation strategies that centre on reducing metal bioavailability only if reduced bioavailability is equated with reduced risk, and if the bioavailability reductions are demonstrated to be long term [66]. For heavy metal-contaminated soils, the physical and chemical form of the heavy metal contaminant in soil strongly influences the selection of the appropriate remediation treatment approach. Information about the physical
TABLE 1: Soil concentration ranges and regulatory guidelines for some heavy metals.

\begin{tabular}{lcc}
\hline Metal & $\begin{array}{c}\text { Soil concentration range } \\
\left(\mathrm{mg} \mathrm{kg}^{-1}\right)\end{array}$ & $\begin{array}{c}\text { Regulatory limits } \\
\left(\mathrm{mg} \mathrm{kg}^{-1}\right)\end{array}$ \\
\hline $\mathrm{Pb}$ & $1.00-69000$ & 600 \\
$\mathrm{Cd}$ & $0.10-345$ & 100 \\
$\mathrm{Cr}$ & $0.05-3950$ & 100 \\
$\mathrm{Hg}$ & $<0.01-1800$ & 270 \\
$\mathrm{Zn}$ & $150-5000$ & 1500 \\
\hline
\end{tabular}

${ }^{\dagger}[64] ;{ }^{\ddagger}$ Nonresidential direct contact soil clean-up criteria [65].

TABLE 2: Target and intervention values for some metals for a standard soil [60].

\begin{tabular}{lcc}
\hline Metal & $\begin{array}{c}\text { Target value } \\
\left(\mathrm{mg} \mathrm{kg}^{-1}\right)\end{array}$ & $\begin{array}{c}\text { Intervention value } \\
\left(\mathrm{mg} \mathrm{kg}^{-1}\right)\end{array}$ \\
\hline $\mathrm{Ni}$ & 140.00 & 720.00 \\
$\mathrm{Cu}$ & 0.30 & 10.00 \\
$\mathrm{Zn}$ & - & - \\
$\mathrm{Cd}$ & 100.00 & 380.00 \\
$\mathrm{~Pb}$ & 35.00 & 210.00 \\
$\mathrm{As}$ & 200 & 625 \\
$\mathrm{Cr}$ & 20 & 240 \\
$\mathrm{Hg}$ & 85 & 530 \\
\hline
\end{tabular}

characteristics of the site and the type and level of contamination at the site must be obtained to enable accurate assessment of site contamination and remedial alternatives. The contamination in the soil should be characterized to establish the type, amount, and distribution of heavy metals in the soil. Once the site has been characterized, the desired level of each metal in soil must be determined. This is done by comparison of observed heavy metal concentrations with soil quality standards for a particular regulatory domain, or by performance of a site-specific risk assessment. Remediation goals for heavy metals may be set as total metal concentration or as leachable metal in soil, or as some combination of these.

Several technologies exist for the remediation of metalcontaminated soil. Gupta et al. [67] have classified remediation technologies of contaminated soils into three categories of hazard-alleviating measures: (i) gentle in situ remediation, (ii) in situ harsh soil restrictive measures, and (iii) in situ or ex situ harsh soil destructive measures. The goal of the last two harsh alleviating measures is to avert hazards either to man, plant, or animal while the main goal of gentle in situ remediation is to restore the malfunctionality of soil (soil fertility), which allows a safe use of the soil. At present, a variety of approaches have been suggested for remediating contaminated soils. USEPA [68] has broadly classified remediation technologies for contaminated soils into (i) source control and (ii) containment remedies. Source control involves in situ and ex situ treatment technologies for sources of contamination. In situ or in place means that the contaminated soil is treated in its original place; unmoved, unexcavated; remaining at the site or in the subsurface. In situ treatment technologies treat or remove the contaminant 
from soil without excavation or removal of the soil. Ex situ means that the contaminated soil is moved, excavated, or removed from the site or subsurface. Implementation of ex situ remedies requires excavation or removal of the contaminated soil. Containment remedies involve the construction of vertical engineered barriers (VEB), caps, and liners used to prevent the migration of contaminants.

Another classification places remediation technologies for heavy metal-contaminated soils under five categories of general approaches to remediation (Table 3): isolation, immobilization, toxicity reduction, physical separation, and extraction [3]. In practice, it may be more convenient to employ a hybrid of two or more of these approaches for more cost effectiveness. The key factors that may influence the applicability and selection of any of the available remediation technologies are: (i) cost, (ii) long-term effectiveness/permanence, (iii) commercial availability, (iv) general acceptance, (v) applicability to high metal concentrations, (vi) applicability to mixed wastes (heavy metals and organics), (vii) toxicity reduction, (viii) mobility reduction, and (ix) volume reduction. The present paper focuses on soil washing, phytoremediation, and immobilization techniques since they are among the best demonstrated available technologies (BDATs) for heavy metal-contaminated sites.

5.1. Immobilization Techniques. Ex situ and in situ immobilization techniques are practical approaches to remediation of metal-contaminated soils. The ex situ technique is applied in areas where highly contaminated soil must be removed from its place of origin, and its storage is connected with a high ecological risk (e.g., in the case of radio nuclides). The method's advantages are: (i) fast and easy applicability and (ii) relatively low costs of investment and operation. The method's disadvantages include (i) high invasivity to the environment, (ii) generation of a significant amount of solid wastes (twice as large as volume after processing), (iii) the byproduct must be stored on a special landfill site, (iv) in the case of changing of the physicochemical condition in the side product or its surroundings, there is serious danger of the release of additional contaminants to the environment, and (v) permanent control of the stored wastes is required. In the in situ technique, the fixing agents amendments are applied on the unexcavated soil. The technique's advantages are (i) its low invasivity, (ii) simplicity and rapidity, (iii) relatively inexpensive, and (iv) small amount of wastes are produced, (v) high public acceptability, (vi) covers a broad spectrum of inorganic pollutants. The disadvantages of in situ immobilization are (i) its only a temporary solution (contaminants are still in the environment), (ii) the activation of pollutants may occur when soil physicochemical properties change, (iii) the reclamation process is applied only to the surface layer of soil $(30-50 \mathrm{~cm})$, and (iv) permanent monitoring is necessary $[66,69]$.

Immobilization technology often uses organic and inorganic amendment to accelerate the attenuation of metal mobility and toxicity in soils. The primary role of immobilizing amendments is to alter the original soil metals to more geochemically stable phases via sorption, precipitation, and
TABLE 3: Technologies for remediation of heavy metal-contaminated soils.

\begin{tabular}{ll}
\hline Category & Remediation technologies \\
\hline Isolation & (i) Capping (ii) subsurface barriers. \\
Immobilization & $\begin{array}{l}\text { (i) Solidification/stabilization (ii) vitrification } \\
\text { (iii) chemical treatment. }\end{array}$ \\
& (i) Chemical treatment (ii) permeable treatment \\
Toxicity and/or & walls (iii) biological treatment bioaccumulation, \\
mobility & $\begin{array}{l}\text { phytoremediation (phytoextraction, } \\
\text { phytostabilization, and rhizofiltration), } \\
\text { reduction }\end{array}$ \\
& bioleaching, biochemical processes.
\end{tabular}

Physical

separation

Extraction

(i) Soil washing, pyrometallurgical extraction, in situ soil flushing, and electrokinetic treatment.

complexation processes [70]. The mostly applied amendments include clay, cement, zeolites, minerals, phosphates, organic composts, and microbes [3, 71]. Recent studies have indicated the potential of low-cost industrial residues such as red mud [72,73] and termitaria [74] in immobilization of heavy metals in contaminated soils. Due to the complexity of soil matrix and the limitations of current analytical techniques, the exact immobilization mechanisms have not been clarified, which could include precipitation, chemical adsorption and ion exchange, surface precipitation, formation of stable complexes with organic ligands, and redox reaction [75]. Most immobilization technologies can be performed ex situ or in situ. In situ processes are preferred due to the lower labour and energy requirements, but implementation of in situ will depend on specific site conditions.

5.1.1. Solidification/Stabilization (S/S). Solidification involves the addition of binding agents to a contaminated material to impart physical/dimensional stability to contain contaminants in a solid product and reduce access by external agents through a combination of chemical reaction, encapsulation, and reduced permeability/surface area. Stabilization (also referred to as fixation) involves the addition of reagents to the contaminated soil to produce more chemically stable constituents. Conventional S/S is an established remediation technology for contaminated soils and treatment technology for hazardous wastes in many countries in the world [76].

The general approach for solidification/stabilization treatment processes involves mixing or injecting treatment agents to the contaminated soils. Inorganic binders (Table 4), such as clay (bentonite and kaolinite), cement, fly ash, blast furnace slag, calcium carbonate, $\mathrm{Fe} / \mathrm{Mn}$ oxides, charcoal, zeolite $[9,77]$, and organic stabilizers (Table 5) such as bitumen, composts, and manures [78], or a combination of organic-inorganic amendments may be used. The dominant mechanism by which metals are immobilized is by precipitation of hydroxides within the solid matrix [79, 80]. Solidification/stabilization technologies are not useful for some forms of metal contamination, such as species that exist as oxyanions (e.g., $\mathrm{Cr}_{2} \mathrm{O}_{7}{ }^{2-}, \mathrm{AsO}_{3}{ }^{-}$) or metals that do 
TABLE 4: Organic amendments for heavy metal immobilization [82].

\begin{tabular}{lc}
\hline Material & $\begin{array}{c}\text { Heavy metal } \\
\text { immobilized }\end{array}$ \\
\hline Bark saw dust (from timber industry) & $\mathrm{Cd}, \mathrm{Pb}, \mathrm{Hg}, \mathrm{Cu}$ \\
Xylogen (from paper mill wastewater) & $\mathrm{Zn}, \mathrm{Pb}, \mathrm{Hg}$ \\
Chitosan (from crab meat canning industry) & $\mathrm{Cd}, \mathrm{Cr}, \mathrm{Hg}$ \\
Bagasse (from sugar cane) & $\mathrm{Pb}$ \\
Poultry manure (from poultry farm) & $\mathrm{Cu}, \mathrm{Pb}, \mathrm{Zn}, \mathrm{Cd}$ \\
Cattle manure (from cattle farm) & $\mathrm{Cd}$ \\
Rice hulls (from rice processing) & $\mathrm{Cd}, \mathrm{Cr}, \mathrm{Pb}$ \\
Sewage sludge & $\mathrm{Cd}$ \\
Leaves & $\mathrm{Cr}, \mathrm{Cd}$ \\
Straw & $\mathrm{Cd}, \mathrm{Cr}, \mathrm{Pb}$ \\
\hline
\end{tabular}

TABLE 5: Inorganic amendments for heavy metal immobilization [82].

\begin{tabular}{lc}
\hline Material & $\begin{array}{c}\text { Heavy metal } \\
\text { immobilized }\end{array}$ \\
\hline Lime (from lime factory) & $\mathrm{Cd}, \mathrm{Cu}, \mathrm{Ni}, \mathrm{Pb}, \mathrm{Zn}$, \\
Phosphate salt (from fertilizer plant) & $\mathrm{Pb}, \mathrm{Zn}, \mathrm{Cu}, \mathrm{Cd}$ \\
Hydroxyapatite (from phosphorite) & $\mathrm{Zn}, \mathrm{Pb}, \mathrm{Cu}, \mathrm{Cd}$ \\
Fly ash (from thermal power plant) & $\mathrm{Cd}, \mathrm{Pb}, \mathrm{Cu}, \mathrm{Zn}, \mathrm{Cr}$ \\
Slag (from thermal power plant) & $\mathrm{Cd}, \mathrm{Pb}, \mathrm{Zn}, \mathrm{Cr}$ \\
Ca-montmorillonite (mineral) & $\mathrm{Zn}, \mathrm{Pb}$ \\
Portland cement (from cement plant) & $\mathrm{Cr}, \mathrm{Cu}, \mathrm{Zn}, \mathrm{Pb}$ \\
Bentonite & $\mathrm{Pb}$ \\
\hline
\end{tabular}

not have low-solubility hydroxides (e.g., Hg). Solidification/stabilization may not be applicable at sites containing wastes that include organic forms of contamination, especially if volatile organics are present. Mixing and heating associated with binder hydration may release organic vapors. Pretreatment, such as air stripping or incineration, may be used to remove the organics and prepare the waste for metal stabilization/solidification [39]. The application of S/S technologies will also be affected by the chemical composition of the contaminated matrix, the amount of water present, and the ambient temperature. These factors can interfere with the solidification/stabilization process by inhibiting bonding of the waste to the binding material, retarding the setting of the mixtures, decreasing the stability of the matrix, or reducing the strength of the solidified area [81].

Cement-based binders and stabilizers are common materials used for implementation of S/S technologies [83]. Portland cement, a mixture of Ca silicates, aluminates, aluminoferrites, and sulfates, is an important cement-based material. Pozzolanic materials, which consist of small spherical particles formed by coal combustion (such as fly ash) and in lime and cement kilns, are also commonly used for S/S. Pozzolans exhibit cement-like properties, especially if the silica content is high. Portland cement and pozzolans can be used alone or together to obtain optimal properties for a particular site [84]. Organic binders may also be used to treat metals through polymer microencapsulation. This process uses organic materials such as bitumen, polyethylene, paraffins, waxes, and other polyolefins as thermoplastic or thermosetting resins. For polymer encapsulation, the organic materials are heated and mixed with the contaminated matrix at elevated temperatures $\left(120^{\circ}\right.$ to $\left.200^{\circ} \mathrm{C}\right)$. The organic materials polymerize and agglomerate the waste, and the waste matrix is encapsulated [84]. Organics are volatilized and collected, and the treated material is extruded for disposal or possible reuse (e.g., as paving material) [39]. The contaminated material may require pretreatment to separate rocks and debris and dry the feed material. Polymer encapsulation requires more energy and more complex equipment than cementbased S/S operations. Bitumen (asphalt) is the cheapest and most common thermoplastic binder [84]. Solidification/stabilization is achieved by mixing the contaminated material with appropriate amounts of binder/stabilizer and water. The mixture sets and cures to form a solidified matrix and contain the waste. The cure time and pour characteristics of the mixture and the final properties of the hardened cement depend upon the composition (amount of cement, pozzolan, and water) of the binder/stabilizer.

Ex situ S/S can be easily applied to excavated soils because methods are available to provide the vigorous mixing needed to combine the binder/stabilizer with the contaminated material. Pretreatment of the waste may be necessary to screen and crush large rocks and debris. Mixing can be performed via in-drum, in-plant, or area-mixing processes. Indrum mixing may be preferred for treatment of small volumes of waste or for toxic wastes. In-plant processes utilize rotary drum mixers for batch processes or pug mill mixers for continuous treatment. Larger volumes of waste may be excavated and moved to a contained area for area mixing. This process involves layering the contaminated material with the stabilizer/binder, and subsequent mixing with a backhoe or similar equipment. Mobile and fixed treatment plants are available for ex situ S/S treatment. Smaller pilotscale plants can treat up to 100 tons of contaminated soil per day while larger portable plants typically process 500 to over 1000 tons per day [39]. Stabilization/stabilization techniques are available to provide mixing of the binder/stabilizer with the contaminated soil in situ. In situ S/S is less labor and energy intensive than ex situ process that require excavation, transport, and disposal of the treated material. In situ S/S is also preferred if volatile or semivolatile organics are present because excavation would expose these contaminants to the air [85]. However, the presence of bedrock, large boulders cohesive soils, oily sands, and clays may preclude the application of in situ S/S at some sites. It is also more difficult to provide uniform and complete mixing through in situ processes. Mixing of the binder and contaminated matrix may be achieved using in-place mixing, vertical auger mixing, or injection grouting. In-place mixing is similar to ex situ area mixing except that the soil is not excavated prior to treatment. The in situ process is useful for treating surface or shallow contamination and involves spreading and mixing the binders with the waste using conventional excavation equipment such as draglines, backhoes, or clamshell buckets. 
Vertical auger mixing uses a system of augers to inject and mix the binding reagents with the waste. Larger $(6-12 \mathrm{ft}$ diameter) augers are used for shallow (10-40 ft) drilling and can treat $500-1000$ cubic yards per day $[86,87]$. Deep stabilization/solidification (up to $150 \mathrm{ft}$ ) can be achieved by using ganged augers (up to $3 \mathrm{ft}$ in diameter each) that can treat $150-400$ cubic yards per day. Finally injection grouting may be performed to inject the binder containing suspended or dissolved reagents into the treatment area under pressure. The binder permeates the surrounding soil and cures in place [39].

5.1.2. Vitrification. The mobility of metal contaminants can be decreased by high-temperature treatment of the contaminated area that results in the formation of vitreous material, usually an oxide solid. During this process, the increased temperature may also volatilize and/or destroy organic contaminants or volatile metal species (such as $\mathrm{Hg}$ ) that must be collected for treatment or disposal. Most soils can be treated by vitrification, and a wide variety of inorganic and organic contaminants can be targeted. Vitrification may be performed ex situ or in situ although in situ processes are preferred due to the lower energy requirements and cost [88]. Typical stages in ex situ vitrification processes may include excavation, pretreatment, mixing, feeding, melting and vitrification, off-gas collection and treatment, and forming or casting of the melted product. The energy requirement for melting is the primary factor influencing the cost of ex situ vitrification. Different sources of energy can be used for this purpose, depending on local energy costs. Process heat losses and water content of the feed should be controlled in order to minimize energy requirements. Vitrified material with certain characteristics may be obtained by using additives such as sand, clay, and/or native soil. The vitrified waste may be recycled and used as clean fill, aggregate, or other reusable materials [39]. In situ vitrification (ISV) involves passing electric current through the soil using an array of electrodes inserted vertically into the contaminated region. Each setting of four electrodes is referred to as a melt. If the soil is too dry, it may not provide sufficient conductance, and a trench containing flaked graphite and glass frit (ground glass particles) must be placed between the electrodes to provide an initial flow path for the current. Resistance heating in the starter path melts the soil. The melt grows outward and down as the molten soil usually provides additional conductance for the current. A single melt can treat up to 1000 tons of contaminated soil to depths of 20 feet, at a typical treatment rate of 3 to 6 tons per hour. Larger areas are treated by fusing together multiple individual vitrification zones. The main requirement for in situ vitrification is the ability of the soil melt to carry current and solidify as it cools. If the alkali content $\left(\right.$ as $\mathrm{Na}_{2} \mathrm{O}$ and $\left.\mathrm{K}_{2} \mathrm{O}\right)$ of the soil is too high (1.4 wt\%), the molten soil may not provide enough conductance to carry the current [89].

Vitrification is not a classical immobilization technique. The advantages include (i) easily applied for reclamation of heavily contaminated soils $(\mathrm{Pb}, \mathrm{Cd}, \mathrm{Cr}$, asbestos, and materials containing asbestos), (ii) in the course of applying this method qualification of wastes (from hazardous to neutral) could be changed.

5.1.3. Assessment of Efficiency and Capacity of Immobilization. The efficiency $(E)$ and capacity $(P)$ of different additives for immobilization and field applications can be evaluated using the expressions

$$
\begin{gathered}
E(\%)=\frac{M_{o}-M_{e}}{M_{o}} \times 100, \\
P=\frac{\left(M_{o}-M_{e}\right) V}{m},
\end{gathered}
$$

where $E=$ efficiency of immobilization agent; $P$ = capacity of immobilization agent; $M_{e}=$ equilibrium extractable concentration of single metal in the immobilized soil $\left(\mathrm{mg} \mathrm{L}^{-1}\right)$; $M_{o}=$ initial extractable concentration of single metal in preimmobilized soil $\left(\mathrm{mg} \mathrm{L}^{-1}\right) ; V=$ volume of metal salt solution $\left(\mathrm{mg} \mathrm{L}^{-1}\right) ; m=$ weight of immobilization agent $(\mathrm{g})$ [90]. High values of $E$ and $P$ represent the perfect efficiency and capacity of an additive that can be used in field studies of metal immobilization. After screening out the best efficient additive, another experiment could be conducted to determine the best ratio (soil/additive) for the field-fixing treatment. After the fixing treatment of contaminated soils, a lot of methods including biological and physiochemical experiments could be used to assess the remediation efficiency. Environmental risk could also be estimated after confirming the immobilized efficiency and possible release [89].

5.2. Soil Washing. Soil washing is essentially a volume reduction/waste minimization treatment process. It is done on the excavated (physically removed) soil (ex situ) or on-site (in situ). Soil washing as discussed in this review refers to $e x$ situ techniques that employ physical and/or chemical procedures to extract metal contaminants from soils. During soil washing, (i) those soil particles which host the majority of the contamination are separated from the bulk soil fractions (physical separation), (ii) contaminants are removed from the soil by aqueous chemicals and recovered from solution on a solid substrate (chemical extraction), or (iii) a combination of both [91]. In all cases, the separated contaminants then go to hazardous waste landfill (or occasionally are further treated by chemical, thermal, or biological processes). By removing the majority of the contamination from the soil, the bulk fraction that remains can be (i) recycled on the site being remediated as relatively inert backfill, (ii) used on another site as fill, or (iii) disposed of relatively cheaply as nonhazardous material.

Ex situ soil washing is particularly frequently used in soil remediation because it (i) completely removes the contaminants and hence ensures the rapid cleanup of a contaminated site [92], (ii) meets specific criteria, (iii) reduces or eliminates long-term liability, (iv) may be the most cost-effective solution, and (v) may produce recyclable material or energy [93]. The disadvantages include the fact that the contaminants are simply moved to a different place, where they must be monitored, the risk of spreading contaminated soil and 
dust particles during removal and transport of contaminated soil, and the relatively high cost. Excavation can be the most expensive option when large amounts of soil must be removed, or disposal as hazardous or toxic waste is required.

Acid and chelator soil washing are the two most prevalent removal methods [94]. Soil washing currently involves soil flushing an in situ process in which the washing solution is forced through the in-place soil matrix, ex situ extraction of heavy metals from the soil slurry in reactors, and soil heap leaching. Another heavy metal removal technology is electroremediation, which mostly involves electrokinetic movement of charged particles suspended in the soil solution, initiated by an electric gradient [35]. The metals can be removed by precipitation at the electrodes. Removal of the majority of the contaminants from the soil does not mean that the contaminant-depleted bulk is totally contaminant free. Thus, for soil washing to be successful, the level of contamination in the treated bulk must be below a sitespecific action limit (e.g., based on risk assessment). Cost effectiveness with soil washing is achieved by offsetting processing costs against the ability to significantly reduce the amount of material requiring costly disposal at a hazardous waste landfill [95].

Typically the cleaned fractions from the soil washing process should be $>70-80 \%$ of the original mass of the soil, but, where the contaminants have a very high associated disposal cost, and/or where transport distances to the nearest hazardous waste landfill are substantial, a 50\% reduction might still be cost effective. There is also a generally held opinion that soil washing based on physical separation processes is only cost effective for sandy and granular soils where the clay and silt content (particles less than $0.063 \mathrm{~mm}$ ) is less than $30-35 \%$ of the soil. Soil washing by chemical dissolution of the contaminants is not constrained by the proportion of clay as this fraction can also be leached by the chemical agent. However, clay-rich soils pose other problems such as difficulties with materials handling and solid-liquid separation [96]. Full-scale soil washing plants exist as fixed centralized treatment centres, or as mobile/transportable units. With fixed centralized facilities, contaminated soil is brought to the plant, whereas with mobile/transportable facilities, the plant is transported to a contaminated site, and soil is processed on the site. Where mobile/transportable plant is used, the cost of mobilization and demobilization can be significant. However, where large volumes of soil are to be treated, this cost can be more than offset by reusing clean material on the site (therefore avoiding the cost of transport to an off-site centralized treatment facility, and avoiding the cost of importing clean fill).

5.2.1. Principles of Soil Washing. Soil washing is a volume reduction/waste minimization treatment technology based on physical and/or chemical processes. With physical soil washing, differences between particle grain size, settling velocity, specific gravity, surface chemical behaviour, and rarely magnetic properties are used to separate those particles which host the majority of the contamination from the bulk which are contaminant-depleted. The equipment used is standard mineral processing equipment, which is more generally used in the mining industry [91]. Mineral processing techniques as applied to soil remediation have been reviewed in literature [97].

With chemical soil washing, soil particles are cleaned by selectively transferring the contaminants on the soil into solution. Since heavy metals are sparingly soluble and occur predominantly in a sorbed state, washing the soils with water alone would be expected to remove too low an amount of cations in the leachates, chemical agents have to be added to the washing water [98]. This is achieved by mixing the soil with aqueous solutions of acids, alkalis, complexants, other solvents, and surfactants. The resulting cleaned particles are then separated from the resulting aqueous solution. This solution is then treated to remove the contaminants (e.g., by sorption on activated carbon or ion exchange) $[91,95]$.

The effectiveness of washing is closely related to the ability of the extracting solution to dissolve the metal contaminants in soils. However, the strong bonds between the soil and metals make the cleaning process difficult [99]. Therefore, only extractants capable of dissolving large quantities of metals would be suitable for cleaning purposes. The realization that the goal of soil remediation is to remove the metal and preserve the natural soil properties limits the choice of extractants that can be used in the cleaning process [100].

5.2.2. Chemical Extractants for Soil Washing. Owing to the different nature of heavy metals, extracting solutions that can optimally remove them must be carefully sought during soil washing. Several classes of chemicals used for soil washing include surfactants, cosolvents, cyclodextrins, chelating agents, and organic acids [101-106]. All these soil washing extractants have been developed on a case-by-case basis depending on the contaminant type at a particular site. A few studies have indicated that the solubilization/exchange/extraction of heavy metals by washing solutions differs considerably for different soil types. Strong acids attack and degrade the soil crystalline structure at extended contact times. For less damaging washes, organic acids and chelating agents are often suggested as alternatives to straight mineral acid use [107].

Natural, low-molecular-weight organic acids (LMWOAs) including oxalic, citric, formic, acetic, malic, succinic, malonic, maleic, lactic, aconitic, and fumaric acids are natural products of root exudates, microbial secretions, and plant and animal residue decomposition in soils [108]. Thus metal dissolution by organic acids is likely to be more representative of a mobile metal fraction that is available to biota [109]. The chelating organic acids are able to dislodge the exchangeable, carbonate, and reducible fractions of heavy metals by washing procedures [94]. Although many chelating compounds including citric acid [108], tartaric acid [110], and EDTA $[94,100,111]$ for mobilizing heavy metals have been evaluated, there remain uncertainties as to the optimal choice for full-scale application. The identification and quantification of coexisting solid metal species in the soil before and after treatment are essential to design and assess the efficiency 
of soil-washing technology [4]. A recent study [112] showed that changes in $\mathrm{Ni}, \mathrm{Cu}, \mathrm{Zn}, \mathrm{Cd}$, and $\mathrm{Pb}$ speciation and uptake by maize in a sandy loam before and after washing with three chelating organic acids indicated that EDTA and citric acid appeared to offer greater potentials as chelating agents for remediating the permeable soil. Tartaric acid was, however, recommended in events of moderate contamination.

The use of soil washing to remediate contaminated finegrained soils that contained more than $30 \%$ fines fraction has been reported by several workers [113-115]. Khodadoust et al. [59, 116] have also studied the removal of various metals $(\mathrm{Pb}, \mathrm{Ni}$, and $\mathrm{Zn})$ from field and clay (kaolin) soil samples using a broad spectrum of extractants (chelating agents and organic acids). Chen and Hong [117] reported on the chelating extraction of $\mathrm{Pb}$ and $\mathrm{Cu}$ from an authentic contaminated soil using derivatives of iminodiacetic acid and L-cyestein. Wuana et al. [118] investigated the removal of $\mathrm{Pb}$ and $\mathrm{Cu}$ from kaolin and bulk clay soils using two mineral acids $\left(\mathrm{HCl}\right.$ and $\mathrm{H}_{2} \mathrm{SO}_{4}$ ) and chelating agents (EDTA and oxalic acid). The use of chelating organic acids-citric acid, tartaric acid and EDTA in the simultaneous removal of $\mathrm{Ni}$, $\mathrm{Cu}, \mathrm{Zn}, \mathrm{Cd}$, and $\mathrm{Pb}$ from an experimentally contaminated sandy loam was carried out by Wuana et al. [112]. These studies furnished valuable information on the distribution of heavy metals in the soils and their removal using various extracting solutions.

5.3. Phytoremediation. Phytoremediation, also called green remediation, botanoremediation, agroremediation, or vegetative remediation, can be defined as an in situ remediation strategy that uses vegetation and associated microbiota, soil amendments, and agronomic techniques to remove, contain, or render environmental contaminants harmless $[119,120]$. The idea of using metal-accumulating plants to remove heavy metals and other compounds was first introduced in 1983, but the concept has actually been implemented for the past 300 years on wastewater discharges [121, 122]. Plants may break down or degrade organic pollutants or remove and stabilize metal contaminants. The methods used to phytoremediate metal contaminants are slightly different from those used to remediate sites polluted with organic contaminants. As it is a relatively new technology, phytoremediation is still mostly in its testing stages and as such has not been used in many places as a full-scale application. However, it has been tested successfully in many places around the world for many different contaminants. Phytoremediation is energy efficient, aesthetically pleasing method of remediating sites with lowto-moderate levels of contamination, and it can be used in conjunction with other more traditional remedial methods as a finishing step to the remedial process.

The advantages of phytoremediation compared with classical remediation are that (i) it is more economically viable using the same tools and supplies as agriculture, (ii) it is less disruptive to the environment and does not involve waiting for new plant communities to recolonize the site, (iii) disposal sites are not needed, (iv) it is more likely to be accepted by the public as it is more aesthetically pleasing then traditional methods, (v) it avoids excavation and transport of polluted media thus reducing the risk of spreading the contamination, and (vi) it has the potential to treat sites polluted with more than one type of pollutant. The disadvantages are as follow (i) it is dependant on the growing conditions required by the plant (i.e., climate, geology, altitude, and temperature), (ii) large-scale operations require access to agricultural equipment and knowledge, (iii) success is dependant on the tolerance of the plant to the pollutant, (iv) contaminants collected in senescing tissues may be released back into the environment in autumn, (v) contaminants may be collected in woody tissues used as fuel, (vi) time taken to remediate sites far exceeds that of other technologies, (vii) contaminant solubility may be increased leading to greater environmental damage and the possibility of leaching. Potentially useful phytoremediation technologies for remediation of heavy metal-contaminated soils include phytoextraction (phytoaccumulation), phytostabilization, and phytofiltration [123].

5.3.1. Phytoextraction (Phytoaccumulation). Phytoextraction is the name given to the process where plant roots uptake metal contaminants from the soil and translocate them to their above soil tissues. A plant used for phytoremediation needs to be heavy-metal tolerant, grow rapidly with a high biomass yield per hectare, have high metal-accumulating ability in the foliar parts, have a profuse root system, and a high bioaccumulation factor $[21,124]$. Phytoextraction is, no doubt, a publicly appealing (green) remediation technology [125]. Two approaches have been proposed for phytoextraction of heavy metals, namely, continuous or natural phytoextraction and chemically enhanced phytoextraction $[126,127]$.

Continuous or Natural Phytoextraction. Continuous phytoextraction is based on the use of natural hyperaccumulator plants with exceptional metal-accumulating capacity. Hyperaccumulators are species capable of accumulating metals at levels 100-fold greater than those typically measured in shoots of the common nonaccumulator plants. Thus, a hyperaccumulator plant will concentrate more than $10 \mathrm{mg} \mathrm{kg}^{-1} \mathrm{Hg}, 100 \mathrm{mg} \mathrm{kg}^{-1} \mathrm{Cd}, 1000 \mathrm{mg} \mathrm{kg}^{-1} \mathrm{Co}, \mathrm{Cr}, \mathrm{Cu}$, and $\mathrm{Pb} ; 10000 \mathrm{mg} \mathrm{kg}^{-1} \mathrm{Zn}$ and $\mathrm{Ni}[128,129]$. Hyperaccumulator plant species are used on metalliferous sites due to their tolerance of relatively high levels of pollution. Approximately 400 plant species from at least 45 plant families have been so far, reported to hyperaccumulate metals [22, 127]; some of the families are Brassicaceae, Fabaceae, Euphorbiaceae, Asterraceae, Lamiaceae, and Scrophulariaceae [130, 131]. Crops like alpine pennycress (Thlaspi caerulescens), Ipomea alpine, Haumaniastrum robertii, Astragalus racemosus, Sebertia acuminate have very high bioaccumulation potential for $\mathrm{Cd} / \mathrm{Zn}, \mathrm{Cu}, \mathrm{Co}, \mathrm{Se}$, and $\mathrm{Ni}$, respectively [22]. Willow (Salix viminalis L.), Indian mustard (Brassica juncea L.), corn (Zea mays L.), and sunflower (Helianthus annuus L.) have reportedly shown high uptake and tolerance to heavy metals [132]. A list of some plant hyperaccumulators are given in Table 6. A number of processes are involved during phytoextraction of metals from soil: (i) a metal fraction is 
TABLE 6: Some metal hyperaccumulating plants [21].

\begin{tabular}{lcc}
\hline Plant & Metal & Concentration $\left(\mathrm{mg} \mathrm{kg}^{-1}\right)$ \\
\hline Dicotyledons & & 309 \\
& $\mathrm{Cd}$ & 2667 \\
& $\mathrm{Co}$ & 2667 \\
Cystus ladanifer & $\mathrm{Cr}$ & 4164 \\
& $\mathrm{Ni}$ & 7695 \\
\hline Thlaspi caerulescens & $\mathrm{Zn}$ & $10000-15000$ \\
& $\mathrm{Cd}$ & $10000-15000$ \\
\hline Arabidopsis halleri & $\mathrm{Zn}$ & $5900-31000$ \\
\hline Alyssum sp. & $\mathrm{Cd}$ & $4200-24400$ \\
\hline Brassica junica & $\mathrm{Ni}$ & $10000-15000$ \\
\hline Betula & $\mathrm{Pb}$ & 2600 \\
\hline Grasses & $\mathrm{Zn}$ & 528 \\
Vetiveria zizaniodes & $\mathrm{Zn}$ & \\
Paspalum notatum & & \\
Stenotaphrum secundatum & $\mathrm{Zn}$ & \\
Pennisetum glaucum & & \\
\hline
\end{tabular}

sorbed at root surface, (ii) bioavailable metal moves across cellular membrane into root cells, (iii) a fraction of the metal absorbed into roots is immobilized in the vacuole, (iv) intracellular mobile metal crosses cellular membranes into root vascular tissue (xylem), and ( $\mathrm{v}$ ) metal is translocated from the root to aerial tissues (stems and leaves) [22]. Once inside the plant, most metals are too insoluble to move freely in the vascular system so they usually form carbonate, sulphate, or phosphate precipitate immobilizing them in apoplastic (extracellular) and symplastic (intracellular) compartments [46]. Hyperaccumulators have several beneficial characteristics but may tend to be slow growing and produce low biomass, and years or decades are needed to clean up contaminated sites. To overcome these shortfalls, chemically enhanced phytoextraction has been developed. The approach makes use of high biomass crops that are induced to take up large amounts of metals when their mobility in soil is enhanced by chemical treatment with chelating organic acids [133].

Chelate-Assisted (Induced) Phytoextraction. For more than 10 years, chelant-enhanced phytoextraction of metals from contaminated soils have received much attention as a costeffective alternative to conventional techniques of enhanced soil remediation $[133,134]$. When the chelating agent is applied to the soil, metal-chelant complexes are formed and taken up by the plant, mostly through a passive apoplastic pathway [133]. Unless the metal ion is transported as a noncationic chelate, apoplastic transport is further limited by the high cation exchange capacity of cell walls [46]. Chelators have been isolated from plants that are strongly involved in the uptake of heavy metals and their detoxification. The chelating agent EDTA has become one of the most tested mobilizing amendments for less mobile/available metals such as $\mathrm{Pb}[135,136]$. Chelators have been isolated from plants that are strongly involved in the uptake of heavy metals and their detoxification. The addition of EDTA to a $\mathrm{Pb}$-contaminated soil (total soil $\mathrm{Pb} 2500 \mathrm{mg} \mathrm{kg}^{-1}$ ) increased shoot lead concentration of Zea mays L. (corn) and Pisun sativum (pea) from less than $500 \mathrm{mg} \mathrm{kg}^{-1}$ to more than $10,000 \mathrm{mg} \mathrm{kg}^{-1}$. Enhanced accumulation of metals by plant species with EDTA treatment is attributed to many factors working either singly or in combination. These factors include (i) an increase in the concentration of available metals, (ii) enhanced metal-EDTA complex movement to roots, (iii) less binding of metal-EDTA complexes with the negatively charged cell wall constituents, (iv) damage to physiological barriers in roots either due to greater concentration of metals or EDTA or metal-EDTA complexes, and (v) increased mobility of metals within the plant body when complexed with EDTA compared to free-metal ions facilitating the translocation of metals from roots to shoots [134, 137]. For the chelates tested, the order of effectiveness in increasing $\mathrm{Pb}$ desorption from the soil was EDTA > hydroxyethylethylene-diaminetriacetic acid (HEDTA) > diethylenetriaminepentaacetic acid (DTPA) > ethylenediamine di(ohyroxyphenylacetic acid) EDDHA [135]. Vassil et al. [138] reported that Brassica juncea exposed to $\mathrm{Pb}$ and EDTA in hydroponic solution was able to accumulate up to $55 \mathrm{mM} \mathrm{kg}^{-1} \mathrm{~Pb}$ in dry shoot tissue $(1.1 \% \mathrm{w} / \mathrm{w})$. This represents a 75-fold concentration of lead in shoot over that in solution. A $0.25 \mathrm{mM}$ threshold concentration of EDTA was required to stimulate this dramatic accumulation of both lead and EDTA in shoots. Since EDTA has been associated with high toxicity and persistence in the environment, several other alternatives have been proposed. Of all those, EDDS ([S,S]-ethylenediamine disuccinate) has been introduced as a promising and environmentally friendlier mobilizing agent, especially for $\mathrm{Cu}$ and $\mathrm{Zn}[135,139,140]$. Once the plants have grown and absorbed the metal pollutants, they are harvested and disposed of safely. This process is repeated several times to reduce contamination to acceptable levels.

Interestingly, in the last few years, the possibility of planting metal hyperaccumulator crops over a low-grade ore body or mineralized soil, and then harvesting and incinerating the biomass to produce a commercial bio-ore has been proposed [141] though this is usually reserved for use with precious metals. This process called phytomining offers the possibility of exploiting ore bodies that are otherwise uneconomic to mine, and its effect on the environment is minimal when compared with erosion caused by opencast mining [123, 141].

Assessing the Efficiency of Phytoextraction. Depending on heavy metal concentration in the contaminated soil and the target values sought for in the remediated soil, phytoextraction may involve repeated cropping of the plant until the metal concentration drops to acceptable levels. The ability of the plant to account for the decrease in soil metal concentrations as a function of metal uptake and biomass production plays an important role in achieving regulatory acceptance. Theoretically, metal removal can be accounted for by determining metal concentration in the plant, multiplied by 
the reduction in soil metal concentrations [127]. It should, however, be borne in mind that this approach may be challenged by a number of factors working together during field applications. Practically, the bioaccumulation factor, $f$, amount of metal extracted, $M$ (mg/kg plant) and phytoremediation time, $t_{p}$ (year) [142] can be used to evaluate the plant's phytoextraction efficiency and calculated according to equation (3) [143] by assuming that the plant can be cropped $n$ times each year and metal pollution occurs only in the active rooting zone, that is, top soil layer $(0-20 \mathrm{~cm})$ and still assuming a soil bulk density of $1.3 \mathrm{t} / \mathrm{m}^{3}$, giving a total soil mass of $2600 \mathrm{t} / \mathrm{ha}$.

$$
\begin{gathered}
f=\frac{\text { Metal concentration in plant shoot }}{\text { Metal concentration in soil }}, \\
M(\mathrm{mg} / \mathrm{kg} \text { plant })=\text { Metal concentration in plant tissue } \times \text { Biomass, } \\
t_{p}(\text { year })=\frac{\text { Metal concentration in soil needed to decrease } \times \text { Soil mass }}{\text { Metal concentration in plant shoot } \times \text { Plant shoot biomass } \times n} .
\end{gathered}
$$

Prospects of Phytoextraction. One of the key aspects of the acceptance of phytoextraction pertains to its performance, ultimate utilization of byproducts, and its overall economic viability. Commercialization of phytoextraction has been challenged by the expectation that site remediation should be achieved in a time comparable to other clean-up technologies [123]. Genetic engineering has a great role to play in supplementing the list of plants available for phytoremediation by the use of engineering tools to insert into plants those genes that will enable the plant to metabolize a particular pollutant [144]. A major goal of plant genetic engineering is to enhance the ability of plants to metabolize many of the compounds that are of environmental concern. Currently, some laboratories are using traditional breeding techniques, others are creating protoplast-fusion hybrids, and still others are looking at the direct insertion of novel genes to enhance the metabolic capabilities of plants [144]. On the whole, phytoextraction appears a very promising technology for the removal of metal pollutants from the environment and is at present approaching commercialization.

Possible Utilization of Biomass after Phytoextraction. A serious challenge for the commercialization of phytoextraction has been the disposal of contaminated plant biomass especially in the case of repeated cropping where large tonnages of biomass may be produced. The biomass has to be stored, disposed of or utilized in an appropriate manner so as not to pose any environmental risk. The major constituents of biomass material are lignin, hemicellulose, cellulose, minerals, and ash. It possesses high moisture and volatile matter, low bulk density, and calorific value [127]. Biomass is solar energy fixed in plants in form of carbon, hydrogen, and oxygen (oxygenated hydrocarbons) with a possible general chemical formula $\mathrm{CH}_{1.44} \mathrm{O}_{0.66}$. Controlled combustion and gasification of biomass can yield a mixture of producer gas and/or pyro-gas which leads to the generation of thermal and electrical energy [145]. Composting and compacting can be employed as volume reduction approaches to biomass reuse [146]. Ashing of biomass can produce bio-ores especially after the phytomining of precious metals. Heavy metals such as $\mathrm{Co}, \mathrm{Cu}, \mathrm{Fe}, \mathrm{Mn}, \mathrm{Mo}, \mathrm{Ni}$, and $\mathrm{Zn}$ are plant essential metals, and most plants have the ability to accumulate them [147]. The high concentrations of these metals in the harvested biomass can be "diluted" to acceptable concentrations by combining the biomass with clean biomass in formulations of fertilizer and fodder.

5.3.2. Phytostabilization. Phytostabilization, also referred to as in-place inactivation, is primarily concerned with the use of certain plants to immobilize soil sediment and sludges [148]. Contaminant are absorbed and accumulated by roots, adsorbed onto the roots, or precipitated in the rhizosphere. This reduces or even prevents the mobility of the contaminants preventing migration into the groundwater or air and also reduces the bioavailability of the contaminant thus preventing spread through the food chain. Plants for use in phytostabilization should be able to (i) decrease the amount of water percolating through the soil matrix, which may result in the formation of a hazardous leachate, (ii) act as barrier to prevent direct contact with the contaminated soil, and (iii) prevent soil erosion and the distribution of the toxic metal to other areas [46]. Phytostabilization can occur through the process of sorption, precipitation, complexation, or metal valence reduction. This technique is useful for the cleanup of $\mathrm{Pb}, \mathrm{As}, \mathrm{Cd}, \mathrm{Cr}, \mathrm{Cu}$, and $\mathrm{Zn}$ [147]. It can also be used to reestablish a plant community on sites that have been denuded due to the high levels of metal contamination. Once a community of tolerant species has been established, the potential for wind erosion (and thus spread of the pollutant) is reduced, and leaching of the soil contaminants is also reduced. Phytostabilization is advantageous because disposal of hazardous material/biomass is not required, and it is very effective when rapid immobilization is needed to preserve ground and surface waters $[147,148]$.

5.3.3. Phytofiltration. Phytofiltration is the use of plant roots (rhizofiltration) or seedlings (blastofiltration), is similar in concept to phytoextraction, but is used to absorb or adsorb pollutants, mainly metals, from groundwater and aqueouswaste streams rather than the remediation of polluted soils $[3,123]$. Rhizosphere is the soil area immediately surrounding the plant root surface, typically up to a few millimetres 
from the root surface. The contaminants are either adsorbed onto the root surface or are absorbed by the plant roots. Plants used for rhizofiltration are not planted directly in situ but are acclimated to the pollutant first. Plants are hydroponically grown in clean water rather than soil, until a large root system has developed. Once a large root system is in place, the water supply is substituted for a polluted water supply to acclimatize the plant. After the plants become acclimatized, they are planted in the polluted area where the roots uptake the polluted water and the contaminants along with it. As the roots become saturated, they are harvested and disposed of safely. Repeated treatments of the site can reduce pollution to suitable levels as was exemplified in Chernobyl where sunflowers were grown in radioactively contaminated pools [21].

\section{Conclusion}

Background knowledge of the sources, chemistry, and potential risks of toxic heavy metals in contaminated soils is necessary for the selection of appropriate remedial options. Remediation of soil contaminated by heavy metals is necessary in order to reduce the associated risks, make the land resource available for agricultural production, enhance food security, and scale down land tenure problems. Immobilization, soil washing, and phytoremediation are frequently listed among the best available technologies for cleaning up heavy metal contaminated soils but have been mostly demonstrated in developed countries. These technologies are recommended for field applicability and commercialization in the developing countries also where agriculture, urbanization, and industrialization are leaving a legacy of environmental degradation.

\section{References}

[1] S. Khan, Q. Cao, Y. M. Zheng, Y. Z. Huang, and Y. G. Zhu, "Health risks of heavy metals in contaminated soils and food crops irrigated with wastewater in Beijing, China," Environmental Pollution, vol. 152, no. 3, pp. 686-692, 2008.

[2] M. K. Zhang, Z. Y. Liu, and H. Wang, "Use of single extraction methods to predict bioavailability of heavy metals in polluted soils to rice," Communications in Soil Science and Plant Analysis, vol. 41, no. 7, pp. 820-831, 2010.

[3] GWRTAC, "Remediation of metals-contaminated soils and groundwater," Tech. Rep. TE-97-01,, GWRTAC, Pittsburgh, Pa, USA, 1997, GWRTAC-E Series.

[4] T. A. Kirpichtchikova, A. Manceau, L. Spadini, F. Panfili, M. A. Marcus, and T. Jacquet, "Speciation and solubility of heavy metals in contaminated soil using X-ray microfluorescence, EXAFS spectroscopy, chemical extraction, and thermodynamic modeling," Geochimica et Cosmochimica Acta, vol. 70, no. 9, pp. 2163-2190, 2006.

[5] D. C. Adriano, Trace Elements in Terrestrial Environments: Biogeochemistry, Bioavailability and Risks of Metals, Springer, New York, NY, USA, 2nd edition, 2003.

[6] P. Maslin and R. M. Maier, "Rhamnolipid-enhanced mineralization of phenanthrene in organic-metal co-contaminated soils," Bioremediation Journal, vol. 4, no. 4, pp. 295-308, 2000 .
[7] M. J. McLaughlin, B. A. Zarcinas, D. P. Stevens, and N. Cook, "Soil testing for heavy metals," Communications in Soil Science and Plant Analysis, vol. 31, no. 11-14, pp. 1661-1700, 2000.

[8] M. J. McLaughlin, R. E. Hamon, R. G. McLaren, T. W. Speir, and S. L. Rogers, "Review: a bioavailability-based rationale for controlling metal and metalloid contamination of agricultural land in Australia and New Zealand," Australian Journal of Soil Research, vol. 38, no. 6, pp. 1037-1086, 2000.

[9] W. Ling, Q. Shen, Y. Gao, X. Gu, and Z. Yang, "Use of bentonite to control the release of copper from contaminated soils," Australian Journal of Soil Research, vol. 45, no. 8, pp. 618-623, 2007.

[10] A. Kabata-Pendias and H. Pendias, Trace Metals in Soils and Plants, CRC Press, Boca Raton, Fla, USA, 2nd edition, 2001.

[11] Q. Zhao and J. J. Kaluarachchi, "Risk assessment at hazardous waste-contaminated sites with variability of population characteristics," Environment International, vol. 28, no. 1-2, pp. 41-53, 2002.

[12] N. S. Bolan, B.G. Ko, C.W.N. Anderson, and I. Vogeler, "Solute interactions in soils in relation to bioavailability and remediation of the environment," in Proceedings of the 5th International Symposium of Interactions of Soil Minerals with Organic Components and Microorganisms, Pucón, Chile, November 2008.

[13] G. M. Pierzynski, J. T. Sims, and G. F. Vance, Soils and Environmental Quality, CRC Press, London, UK, 2nd edition, 2000.

[14] J. J. D’Amore, S. R. Al-Abed, K. G. Scheckel, and J. A. Ryan, "Methods for speciation of metals in soils: a review," Journal of Environmental Quality, vol. 34, no. 5, pp. 1707-1745, 2005.

[15] B. J. Alloway, Heavy Metals in Soils, Blackie Academic and Professional, London, UK, 2nd edition, 1995.

[16] E. Lombi and M. H. Gerzabek, "Determination of mobile heavy metal fraction in soil: results of a pot experiment with sewage sludge," Communications in Soil Science and Plant Analysis, vol. 29, no. 17-18, pp. 2545-2556, 1998.

[17] G. Sposito and A. L. Page, "Cycling of metal ions in the soil environment," in Metal Ions in Biological Systems, H. Sigel, Ed., vol. 18 of Circulation of Metals in the Environment, pp. 287-332, Marcel Dekker, Inc., New York, NY, USA, 1984.

[18] S. Kuo, P. E. Heilman, and A. S. Baker, "Distribution and forms of copper, zinc, cadmium, iron, and manganese in soils near a copper smelter," Soil Science, vol. 135, no. 2, pp. 101109, 1983.

[19] M. Kaasalainen and M. Yli-Halla, "Use of sequential extraction to assess metal partitioning in soils," Environmental Pollution, vol. 126, no. 2, pp. 225-233, 2003.

[20] N. T. Basta, J. A. Ryan, and R. L. Chaney, "Trace element chemistry in residual-treated soil: key concepts and metal bioavailability," Journal of Environmental Quality, vol. 34, no. 1, pp. 49-63, 2005.

[21] A. Scragg, Environmental Biotechnology, Oxford University Press, Oxford, UK, 2nd edition, 2006.

[22] M.M. Lasat, "Phytoextraction of metals from contaminated soil: a review of plant/soil/metal interaction and assessment of pertinent agronomic issues," Journal of Hazardous Substances Research, vol. 2, pp. 1-25, 2000.

[23] L. H. P. Jones and S. C. Jarvis, "The fate of heavy metals," in The Chemistry of Soil Processes, D. J. Green and M. H. B. Hayes, Eds., p. 593, John Wiley \& Sons, New York, NY, USA, 1981. 
[24] P. H. Raven, L. R. Berg, and G. B. Johnson, Environment, Saunders College Publishing, New York, NY, USA, 2nd edition, 1998.

[25] M. E. Sumner, "Beneficial use of effluents, wastes, and biosolids," Communications in Soil Science and Plant Analysis, vol. 31, no. 11-14, pp. 1701-1715, 2000.

[26] R. L. Chaney and D. P. Oliver, "Sources, potential adverse effects and remediation of agricultural soil contaminants," in Contaminants and the Soil Environments in the AustraliaPacific Region, R. Naidu, Ed., pp. 323-359, Kluwer Academic Publishers, Dordrecht, The Netherlands, 1996.

[27] USEPA, "A plain english guide to the EPA part 503 biosolids rule," USEPA Rep. 832/R-93/003, USEPA, Washington, DC, USA, 1994.

[28] K. Weggler, M. J. McLaughlin, and R. D. Graham, "Effect of Chloride in Soil Solution on the Plant Availability of Biosolid-Borne Cadmium," Journal of Environmental Quality, vol. 33, no. 2, pp. 496-504, 2004.

[29] M. L. A. Silveira, L. R. F. Alleoni, and, and L. R. G. Guilherme, "Biosolids and heavy metals in soils," Scientia Agricola, vol. 60, no. 4, pp. 64-111, 2003.

[30] R. Canet, F. Pomares, F. Tarazona, and M. Estela, "Sequential fractionation and plant availability of heavy metals as affected by sewage sludge applications to soil," Communications in Soil Science and Plant Analysis, vol. 29, no. 5-6, pp. 697-716, 1998.

[31] S. V. Mattigod and A. L. Page, "Assessment of metal pollution in soil," in Applied Environmental Geochemistry, pp. 355-394, Academic Press, London, UK, 1983.

[32] R. G. McLaren, L. M. Clucas, and M. D. Taylor, "Leaching of macronutrients and metals from undisturbed soils treated with metal-spiked sewage sludge. 3. Distribution of residual metals," Australian Journal of Soil Research, vol. 43, no. 2, pp. 159-170, 2005.

[33] C. Keller, S. P. McGrath, and S. J. Dunham, "Trace metal leaching through a soil-grassland system after sewage sludge application," Journal of Environmental Quality, vol. 31, no. 5, pp. 1550-1560, 2002.

[34] R. G. McLaren, L. M. Clucas, M. D. Taylor, and T. Hendry, "Leaching of macronutrients and metals from undisturbed soils treated with metal-spiked sewage sludge. 2. Leaching of metals," Australian Journal of Soil Research, vol. 42, no. 4, pp. 459-471, 2004.

[35] S. C. Reed, R. W. Crites, and E. J. Middlebrooks, Natural Systems for Waste Management and Treatment, McGraw-Hill, New York, NY, USA, 2nd edition, 1995.

[36] J. Bjuhr, Trace Metals in Soils Irrigated with Waste Water in a Periurban Area Downstream Hanoi City, Vietnam, Seminar Paper, Institutionen för markvetenskap, Sveriges lantbruksuniversitet (SLU), Uppsala, Sweden, 2007.

[37] P. S. DeVolder, S. L. Brown, D. Hesterberg, and K. Pandya, "Metal bioavailability and speciation in a wetland tailings repository amended with biosolids compost, wood ash, and sulfate," Journal of Environmental Quality, vol. 32, no. 3, pp. 851-864, 2003.

[38] N. T. Basta and R. Gradwohl, "Remediation of heavy metalcontaminated soil using rock phosphate," Better Crops, vol. 82, no. 4, pp. 29-31, 1998.

[39] L. A. Smith, J. L. Means, A. Chen et al., Remedial Options for Metals-Contaminated Sites, Lewis Publishers, Boca Raton, Fla, USA, 1995.

[40] USEPA, Report: recent Developments for In Situ Treatment of Metals contaminated Soils, U.S. Environmental Protection
Agency, Office of Solid Waste and Emergency Response, 1996.

[41] J. Shiowatana, R. G. McLaren, N. Chanmekha, and A. Samphao, "Fractionation of arsenic in soil by a continuousflow sequential extraction method," Journal of Environmental Quality, vol. 30, no. 6, pp. 1940-1949, 2001.

[42] J. Buekers, Fixation of cadmium, copper, nickel and zinc in soil: kinetics, mechanisms and its effect on metal bioavailability, Ph.D. thesis, Katholieke Universiteit Lueven, 2007, Dissertationes De Agricultura, Doctoraatsprooefschrift nr.

[43] D. B. Levy, K. A. Barbarick, E. G. Siemer, and L. E. Sommers, "Distribution and partitioning of trace metals in contaminated soils near Leadville, Colorado," Journal of Environmental Quality, vol. 21, no. 2, pp. 185-195, 1992.

[44] USDHHS, Toxicological profile for lead, United States Department of Health and Human Services, Atlanta, Ga, USA, 1999.

[45] S.E. Manahan, Toxicological Chemistry and Biochemistry, CRC Press, Limited Liability Company (LLC), 3rd edition, 2003.

[46] I. Raskin and B. D. Ensley, Phytoremediation of Toxic Metals:Using Plants to Clean Up the Environment, John Wiley \& Sons, New York, NY, USA, 2000.

[47] NSC, Lead Poisoning, National Safety Council, 2009, http:// www.nsc.org/news_resources/Resources/Documents/Lead_ Poisoning.pdf.

[48] D. R. Baldwin and W. J. Marshall, "Heavy metal poisoning and its laboratory investigation," Annals of Clinical Biochemistry, vol. 36, no. 3, pp. 267-300, 1999.

[49] C.J. Rosen, Lead in the home garden and urban soil environment, Communication and Educational Technology Services, University of Minnesota Extension, 2002.

[50] P. Chrostowski, J. L. Durda, and K. G. Edelmann, "The use of natural processes for the control of chromium migration," Remediation, vol. 2, no. 3, pp. 341-351, 1991.

[51] I. Bodek, W. J. Lyman, W. F. Reehl, and D. H. Rosenblatt, in Environmental Inorganic Chemistry: Properties, Processes and Estimation Methods, Pergamon Press, Elmsford, NY, USA, 1988.

[52] B. E. Davies and L. H. P. Jones, "Micronutrients and toxic elements," in Russell's Soil Conditions and Plant Growth, A. Wild, Ed., pp. 781-814, John Wiley \& Sons; Interscience, New York, NY, USA, 11th edition, 1988.

[53] K. M. Greany, An assessment of heavy metal contamination in the marine sediments of Las Perlas Archipelago, Gulf of Panama, M.S. thesis, School of Life Sciences Heriot-Watt University, Edinburgh, Scotland, 2005.

[54] P. G. C. Campbell, “Cadmium-A priority pollutant," Environmental Chemistry, vol. 3, no. 6, pp. 387-388, 2006.

[55] VCI, Copper history/Future, Van Commodities Inc., 2011, http://trademetalfutures.com/copperhistory.html.

[56] C. E. Martínez and H. L. Motto, "Solubility of lead, zinc and copper added to mineral soils," Environmental Pollution, vol. 107, no. 1, pp. 153-158, 2000.

[57] J. Eriksson, A. Andersson, and R. Andersson, "The state of Swedish farmlands," Tech. Rep. 4778, Swedish Environmental Protection Agency, Stockholm, Sweden, 1997.

[58] M. Pourbaix, Atlas of Electrochemical Equilibria, Pergamon Press, New York, NY, USA, 1974, Translated from French by J.A. Franklin.

[59] A. P. Khodadoust, K. R. Reddy, and K. Maturi, "Removal of nickel and phenanthrene from kaolin soil using different extractants," Environmental Engineering Science, vol. 21, no. 6, pp. 691-704, 2004. 
[60] DPR-EGASPIN, Environmental Guidelines and Standards for the Petroleum Industry in Nigeria (EGASPIN), Department of Petroleum Resources, Lagos, Nigeria, 2002.

[61] A. Tessier, P. G. C. Campbell, and M. Blsson, "Sequential extraction procedure for the speciation of particulate trace metals," Analytical Chemistry, vol. 51, no. 7, pp. 844-851, 1979.

[62] A. M. Ure, PH. Quevauviller, H. Muntau, and B. Griepink, "Speciation of heavy metals in soils and sediments. An account of the improvement and harmonization of extraction techniques undertaken under the auspices of the BCR of Commission of the European Communities," International Journal of Environmental Analytical Chemistry, vol. 51, no. 1, pp. 35-151, 1993.

[63] D. M. DiToro, J. D. Mahony, D. J. Hansen, K. J. Scott, A. R. Carlson, and G. T. Ankley, "Acid volatile sulfide predicts the acute toxicity of cadmium and nickel in sediments," Environmental Science and Technology, vol. 26, no. 1, pp. 96-101, 1992.

[64] R. G. Riley, J. M. Zachara, and F. J. Wobber, "Chemical contaminants on DOE lands and selection of contaminated mixtures for subsurface science research," US-DOE, Energy Resource Subsurface Science Program, Washington, DC, USA, 1992.

[65] NJDEP, Soil Cleanup Criteria, New Jersey Department of Environmental Protection, Proposed Cleanup Standards for Contaminated Sites, NJAC 7:26D, 1996.

[66] T. A. Martin and M. V. Ruby, "Review of in situ remediation technologies for lead, zinc and cadmium in soil," Remediation, vol. 14, no. 3, pp. 35-53, 2004.

[67] S. K. Gupta, T. Herren, K. Wenger, R. Krebs, and T. Hari, "In situ gentle remediation measures for heavy metal-polluted soils," in Phytoremediation of Contaminated Soil and Water, N. Terry and G. Bañuelos, Eds., pp. 303-322, Lewis Publishers, Boca Raton, Fla, USA, 2000.

[68] USEPA, "Treatment technologies for site cleanup: annual status report (12th Edition)," Tech. Rep. EPA-542-R-07-012, Solid Waste and Emergency Response (5203P), Washington, DC, USA, 2007.

[69] USEPA, "Recent developments for in situ treatment of metal contaminated soils," Tech. Rep. EPA-542-R-97-004, USEPA, Washington, DC, USA, 1997.

[70] Y. Hashimoto, H. Matsufuru, M. Takaoka, H. Tanida, and T. Sato, "Impacts of chemical amendment and plant growth on lead speciation and enzyme activities in a shooting range soil: an X-ray absorption fine structure investigation," Journal of Environmental Quality, vol. 38, no. 4, pp. 1420-1428, 2009.

[71] N. Finžgar, B. Kos, and D. Leštan, "Bioavailability and mobility of $\mathrm{Pb}$ after soil treatment with different remediation methods," Plant, Soil and Environment, vol. 52, no. 1, pp. 2534, 2006.

[72] J. Boisson, M. Mench, J. Vangronsveld, A. Ruttens, P. Kopponen, and T. De Koe, "Immobilization of trace metals and arsenic by different soil additives: evaluation by means of chemical extractions," Communications in Soil Science and Plant Analysis, vol. 30, no. 3-4, pp. 365-387, 1999.

[73] E. Lombi, F. J. Zhao, G. Zhang et al., "In situ fixation of metals in soils using bauxite residue: chemical assessment," Environmental Pollution, vol. 118, no. 3, pp. 435-443, 2002.

[74] C. O. Anoduadi, L. B. Okenwa, F. E. Okieimen, A. T. Tyowua, and E.G. Uwumarongie-Ilori, "Metal immobilization in CCA contaminated soil using laterite and termite mound soil. Evaluation by chemical fractionation," Nigerian Journal of Applied Science, vol. 27, pp. 77-87, 2009.
[75] L. Q. Wang, L. Luo, Y. B Ma, D. P. Wei, and L. Hua, "In situ immobilization remediation of heavy metals-contaminated soils: a review," Chinese Journal of Applied Ecology, vol. 20, no. 5, pp. 1214-1222, 2009.

[76] F. R. Evanko and D. A. Dzombak, "Remediation of metals contaminated soils and groundwater," Tech. Rep. TE-9701, Groundwater Remediation Technologies Analysis Centre, Pittsburg, Pa, USA, 1997.

[77] E. M. Fawzy, "Soil remediation using in situ immobilisation techniques," Chemistry and Ecology, vol. 24, no. 2, pp. 147156, 2008.

[78] M. Farrell, W. T. Perkins, P. J. Hobbs, G. W. Griffith, and D. L. Jones, "Migration of heavy metals in soil as influenced by compost amendments," Environmental Pollution, vol. 158, no. 1, pp. 55-64, 2010.

[79] P. Bishop, D. Gress, and J. Olafsson, "Cement stabilization of heavy metals:Leaching rate assessment," in Industrial Wastes- Proceedings of the 14th Mid-Atlantic Industrial Waste Conference, Technomics, Lancaster, Pa, USA, 1982.

[80] W. Shively, P. Bishop, D. Gress, and T. Brown, "Leaching tests of heavy metals stabilized with Portland cement," Journal of the Water Pollution Control Federation, vol. 58, no. 3, pp. 234241, 1986.

[81] USEPA, "Interference mechanisms in waste stabilization/solidification processes," Tech. Rep. EPA/540/A5-89/004, United States Environmental Protection Agency, Office of Research and Development, Cincinnati, Ohio, USA, 1990.

[82] G. Guo, Q. Zhou, and L. Q. Ma, "Availability and assessment of fixing additives for the in situ remediation of heavy metal contaminated soils: a review," Environmental Monitoring and Assessment, vol. 116, no. 1-3, pp. 513-528, 2006.

[83] J. R. Conner, Chemical Fixation and Solidification of Hazardous Wastes, Van Nostrand Reinhold, New York, NY, USA, 1990.

[84] USEPA, "Stabilization/solidification of CERCLA and RCRA wastes," Tech. Rep. EPA/625/6-89/022, United States Environmental Protection Agency, Center for Environmental Research Information, Cincinnati, Ohio, USA, 1989.

[85] USEPA, " International waste technologies/geo-con in situ stabilization/solidification,” Tech. Rep. EPA/540/A5-89/004, United States Environmental Protection Agency, Office of Research and Development, Cincinnati, Ohio, USA, 1990.

[86] B. H. Jasperse and C. R. Ryan, "Stabilization and fixation using soil mixing," in Proceedings of the ASCE Specialty Conference on Grouting, Soil Improvement, and Geosynthetics, ASCE Publications, Reston, Va, USA, 1992.

[87] C. R. Ryan and A. D. Walker, "Soil mixing for soil improvement," in Proceedings of the 23rd Conference on In situ Soil Modification, Geo-Con, Inc., Louisville, Ky, USA, 1992.

[88] USEPA, "Vitrification technologies for treatment of Hazardous and radioactive waste handbook," Tech. Rep. EPA/ 625/R-92/002, United States Environmental Protection Agency, Office of Research and Development, Washington, DC, USA, 1992.

[89] J. L. Buelt and L. E. Thompson, The In situ Vitrification Integrated Program: Focusing on an Innovative Solution on Environmental Restoration Needs, Battelle Pacific Northwest Laboratory, Richland, Wash, USA, 1992.

[90] A. Jang, Y. S. Choi, and I. S. Kim, "Batch and column tests for the development of an immobilization technology for toxic heavy metals in contaminated soils of closed mines," Water Science and Technology, vol. 37, no. 8, pp. 81-88, 1998. 
[91] G. Dermont, M. Bergeron, G. Mercier, and M. RicherLaflèche, "Soil washing for metal removal: a review of physical/chemical technologies and field applications," Journal of Hazardous Materials, vol. 152, no. 1, pp. 1-31, 2008.

[92] P. Wood, "Remediation methods for contaminated sites," in Contaminated Land and Its Reclamation, R. Hester and R. Harrison, Eds., Royal Society of Chemistry, Cambridge, UK, 1997.

[93] GOC, "Site Remediation Technologies: A Reference Manual," 2003, Contaminated Sites Working Group, Government of Canada, Ontario, Canada.

[94] R. W. Peters, "Chelant extraction of heavy metals from contaminated soils," Journal of Hazardous Materials, vol. 66, no. 1-2, pp. 151-210, 1999.

[95] CLAIRE, "Understanding soil washing, contaminated land: applications in real environments," Tech. Rep. TB13, 2007.

[96] M. Pearl and P. Wood, "Review of pilot and full scale soil washing plants," Warren Spring Laboratory Report LR 1018, Department of the Environment, AEA Technology National Environmental Technology Centre, 1994, B551 Harwell, Oxfordshire, OX11 0RA.

[97] A. Gosselin, M. Blackburn, and M. Bergeron, Assessment Protocol of the applicability of ore-processing technology to Treat Contaminated Soils, Sediments and Sludges, prepared for EcoTechnology innovation Section, Eco-Technology Innovation Section, Technology Development and Demonstration Program, Environment Canada, Canada, 1999.

[98] A. P. Davis and I. Singh, "Washing of zinc(II) from contaminated soil column," Journal of Environmental Engineering, vol. 121, no. 2, pp. 174-185, 1995.

[99] D. Gombert, "Soil washing and radioactive contamination," Environmental Progress, vol. 13, no. 2, pp. 138-142, 1994.

[100] R. S. Tejowulan and W. H. Hendershot, "Removal of trace metals from contaminated soils using EDTA incorporating resin trapping techniques," Environmental Pollution, vol. 103, no. 1, pp. 135-142, 1998.

[101] USEPA, "Engineering bulletin: soil washing treatment," Tech. Rep. EPA/540/2-90/017, Office of Emergency and Remedial Response, United States Environmental Protection Agency, Washington, DC, USA, 1990.

[102] A. L. Wood, D. C. Bouchard, M. L. Brusseau, and P. S. C. Rao, "Cosolvent effects on sorption and mobility of organic contaminants in soils," Chemosphere, vol. 21, no. 4-5, pp. 575-587, 1990.

[103] W. Chu and K. H. Chan, "The mechanism of the surfactantaided soil washing system for hydrophobic and partial hydrophobic organics," Science of the Total Environment, vol. 307, no. 1-3, pp. 83-92, 2003.

[104] Y. Gao, J. He, W. Ling, H. Hu, and F. Liu, "Effects of organic acids on copper and cadmium desorption from contaminated soils," Environment International, vol. 29, no. 5, pp. 613-618, 2003.

[105] K. Maturi and K. R. Reddy, "Extractants for the removal of mixed contaminants from soils," Soil and Sediment Contamination, vol. 17, no. 6, pp. 586-608, 2008.

[106] H. Zhang, Z. Dang, L. C. Zheng, and X. Y. Yi, "Remediation of soil co-contaminated with pyrene and cadmium by growing maize (Zea mays L.)," International Journal of Environmental Science and Technology, vol. 6, no. 2, pp. 249258, 2009.

[107] J. Yu and D. Klarup, "Extraction kinetics of copper, zinc, iron, and manganese from contaminated sediment using disodium ethylenediaminetetraacetate," Water, Air, and Soil Pollution, vol. 75, no. 3-4, pp. 205-225, 1994.
[108] R. Naidu and R. D. Harter, "Effect of different organic ligands on cadmium sorption by and extractability from soils," Soil Science Society of America Journal, vol. 62, no. 3, pp. 644-650, 1998.

[109] J. Labanowski, F. Monna, A. Bermond et al., "Kinetic extractions to assess mobilization of $\mathrm{Zn}, \mathrm{Pb}, \mathrm{Cu}$, and $\mathrm{Cd}$ in a metal-contaminated soil: EDTA vs. citrate," Environmental Pollution, vol. 152, no. 3, pp. 693-701, 2008.

[110] X. Ke, P. J. Li, Q. X. Zhou, Y. Zhang, and T. H. Sun, "Removal of heavy metals from a contaminated soil using tartaric acid," Journal of Environmental Sciences, vol. 18, no. 4, pp. 727-733, 2006.

[111] B. Sun, F. J. Zhao, E. Lombi, and S. P. McGrath, "Leaching of heavy metals from contaminated soils using EDTA," Environmental Pollution, vol. 113, no. 2, pp. 111-120, 2001.

[112] R. A. Wuana, F. E. Okieimen, and J. A. Imborvungu, "Removal of heavy metals from a contaminated soil using organic chelating acids," International Journal of Environmental Science and Technology, vol. 7, no. 3, pp. 485-496, 2010.

[113] H. Farrah and W. F. Pickering, "Extraction of heavy metal ions sorbed on clays," Water, Air, and Soil Pollution, vol. 9, no. 4, pp. 491-498, 1978.

[114] B. J. W. Tuin and M. Tels, "Removing heavy metals from contaminated clay soils by extraction with hydrochloric acid, edta or hypochlorite solutions," Environmental Technology, vol. 11, no. 11, pp. 1039-1052, 1990.

[115] K. R. Reddy and S. Chinthamreddy, "Comparison of extractants for removing heavy metals from contaminated clayey soils," Soil and Sediment Contamination, vol. 9, no. 5, pp. 449-462, 2000.

[116] A. P. Khodadoust, K. R. Reddy, and K. Maturi, "Effect of different extraction agents on metal and organic contaminant removal from a field soil," Journal of Hazardous Materials, vol. 117, no. 1, pp. 15-24, 2005.

[117] T. C. Chen and A. Hong, "Chelating extraction of lead and copper from an authentic contaminated soil using $\mathrm{N}$ (2-acetamido)iminodiacetic acid and S-carboxymethyl-Lcysteine," Journal of Hazardous Materials, vol. 41, no. 2-3, pp. 147-160, 1995.

[118] R. A. Wuana, F. E. Okieimen, and R. E. Ikyereve, "Removal of lead and copper from contaminated kaolin and bulk clay soils using acids and chelating agents," Journal of Chemical Society of Nigeria, vol. 33, no. 1, pp. 213-219, 2008.

[119] S. D. Cunningham and D. W. Ow, "Promises and prospects of phytoremediation," Plant Physiology, vol. 110, no. 3, pp. 715-719, 1996.

[120] H. S. Helmisaari, M. Salemaa, J. Derome, O. Kiikkilö, C. Uhlig, and T. M. Nieminen, "Remediation of heavy metalcontaminated forest soil using recycled organic matter and native woody plants," Journal of Environmental Quality, vol. 36, no. 4, pp. 1145-1153, 2007.

[121] R. L. Chaney, M. Malik, Y. M. Li et al., "Phytoremediation of soil metals," Current Opinion in Biotechnology, vol. 8, no. 3, pp. 279-284, 1997.

[122] R. J. Henry, An Overview of the Phytoremediation of Lead and Mercury, United States Environmental Protection Agency Office of Solid Waste and Emergency Response Technology Innovation office, Washington, DC, USA, 2000.

[123] C. Garbisu and I. Alkorta, "Phytoextraction: a cost-effective plant-based technology for the removal of metals from the environment," Bioresource Technology, vol. 77, no. 3, pp. 229236, 2001.

[124] C. D. Jadia and M. H. Fulekar, "Phytotoxicity and remediation of heavy metals by fibrous root grass (sorghum)," 
Journal of Applied Biosciences, vol. 10, no. 1, pp. 491-499, 2008.

[125] M. Vysloužilová, P. Tlustoš, J. Száková, and D. Pavlíková, “As, $\mathrm{Cd}, \mathrm{Pb}$ and $\mathrm{Zn}$ uptake by Salix spp. clones grown in soils enriched by high loads of these elements," Plant, Soil and Environment, vol. 49, no. 5, pp. 191-196, 2003.

[126] E. Lombi, F. J. Zhao, S. J. Dunham, and S. P. McGrath, "Phytoremediation of heavy metal-contaminated soils: natural hyperaccumulation versus chemically enhanced phytoextraction," Journal of Environmental Quality, vol. 30, no. 6, pp. 1919-1926, 2001.

[127] M. Ghosh and S. P. Singh, "A review on phytoremediation of heavy metals and utilization of its byproducts," Applied Ecology and Environmental Research, vol. 3, no. 1, pp. 1-18, 2005.

[128] A. J. M. Baker and R. R. Brooks, “Terrestrial higher plants which hyperaccumulate metallic elements: a review of their distribution, ecology and phytochemistry," Biorecovery, vol. 1, pp. 81-126, 1989.

[129] M. M. Lasat, "Phytoextraction of toxic metals: a review of biological mechanisms," Journal of Environmental Quality, vol. 31, no. 1, pp. 109-120, 2002.

[130] D. E. Salt, R. D. Smith, and I. Raskin, "Phytoremediation," Annual Reviews in Plant Physiology \& Plant Molecular Biology, vol. 49, pp. 643-668, 1998.

[131] S. Dushenkov, "Trends in phytoremediation of radionuclides," Plant and Soil, vol. 249, no. 1, pp. 167-175, 2003.

[132] U. Schmidt, "Enhancing phytoextraction: the effect of chemical soil manipulation on mobility, plant accumulation and leaching of heavy metals," Journal of Environmental Quality, vol. 32, no. 6, pp. 1939-1954, 2003.

[133] B. Nowack, R. Schulin, and B. H. Robinson, "Critical assessment of chelant-enhanced metal phytoextraction," Environmental Science and Technology, vol. 40, no. 17, pp. 5225-5232, 2006.

[134] M. W. H. Evangelou, M. Ebel, and A. Schaeffer, "Chelate assisted phytoextraction of heavy metals from soil. Effect, mechanism, toxicity, and fate of chelating agents," Chemosphere, vol. 68, no. 6, pp. 989-1003, 2007.

[135] J. W. Huang, J. Chen, W. R. Berti, and S. D. Cunningham, "Phytoremediadon of lead-contaminated soils: role of synthetic chelates in lead phytoextraction," Environmental Science and Technology, vol. 31, no. 3, pp. 800-805, 1997.

[136] Saifullah, E. Meers, M. Qadir et al., "EDTA-assisted Pb phytoextraction," Chemosphere, vol. 74, no. 10, pp. 1279-1291, 2009.

[137] Y. Xu, N. Yamaji, R. Shen, and J. F. Ma, "Sorghum roots are inefficient in uptake of EDTA-chelated lead," Annals of Botany, vol. 99, no. 5, pp. 869-875, 2007.

[138] A. D. Vassil, Y. Kapulnik, I. Raskin, and D. E. Sait, "The role of EDTA in lead transport and accumulation by Indian mustard," Plant Physiology, vol. 117, no. 2, pp. 447-453, 1998.

[139] B. Kos and D. Leštan, "Chelator induced phytoextraction and in situ soil washing of Cu," Environmental Pollution, vol. 132, no. 2, pp. 333-339, 2004.

[140] S. Tandy, K. Bossart, R. Mueller et al., "Extraction of heavy metals from soils using biodegradable chelating agents," Environmental Science and Technology, vol. 38, no. 3, pp. 937944, 2004.

[141] R. R. Brooks, M. F. Chambers, L. J. Nicks, and B. H. Robinson, "Phytomining," Trends in Plant Science, vol. 3, no. 9, pp. 359-362, 1998.
[142] P. Zhuang, Z. H. Ye, C. Y. Lan, Z. W. Xie, and W. S. Shu, "Chemically assisted phytoextraction of heavy metal contaminated soils using three plant species," Plant and Soil, vol. 276, no. 1-2, pp. 153-162, 2005.

[143] X. Zhang, H. Xia, Z. Li, P. Zhuang, and B. Gao, "Potential of four forage grasses in remediation of $\mathrm{Cd}$ and $\mathrm{Zn}$ contaminated soils," Bioresource Technology, vol. 101, no. 6, pp. 20632066, 2010.

[144] L. A. Newman, S. E. Strand, N. Choe et al., "Uptake and biotransformation of trichloroethylene by hybrid poplars," Environmental Science and Technology, vol. 31, no. 4, pp. 10621067, 1997.

[145] P. V. R. Iyer, T. R. Rao, and P. D. Grover, Biomass Thermochemical Characterization Characterization, Indian Institute of Technology, Delhi, India, 3rd edition, 2002.

[146] M.D. Hetland, J. R. Gallagher, D. J. Daly, D. J. Hassett, and L. V. Heebink, "Processing of plants used to phytoremediate lead-contaminated sites," A. Leeson, E. A. Forte, M. K. Banks, and V. S. Magar, Eds., pp. 129-136, Batelle Press.

[147] C. D. Jadia and M. H. Fulekar, "Phytoremediation of heavy metals: recent techniques," African Journal of Biotechnology, vol. 8, no. 6, pp. 921-928, 2009.

[148] USEPA, "Introduction to phytoremediation," Tech. Rep. EPA 600/R-99/107, United States Environmental Protection Agency, Office of Research and Development, Cincinnati, Ohio, USA, 2000. 

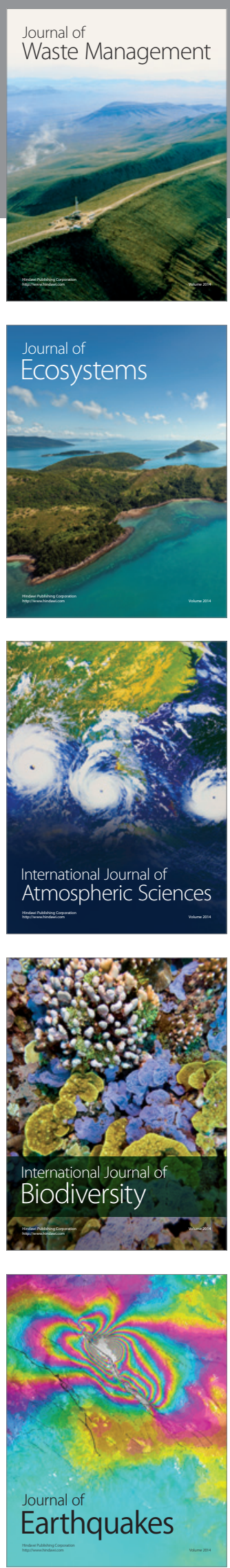
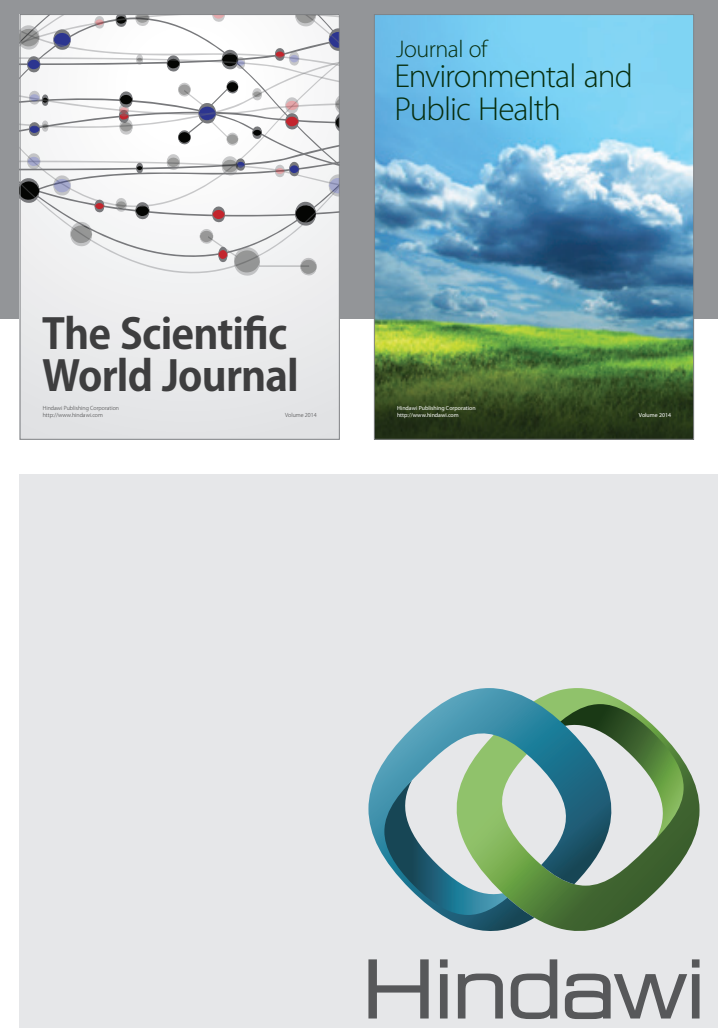

Submit your manuscripts at

http://www.hindawi.com
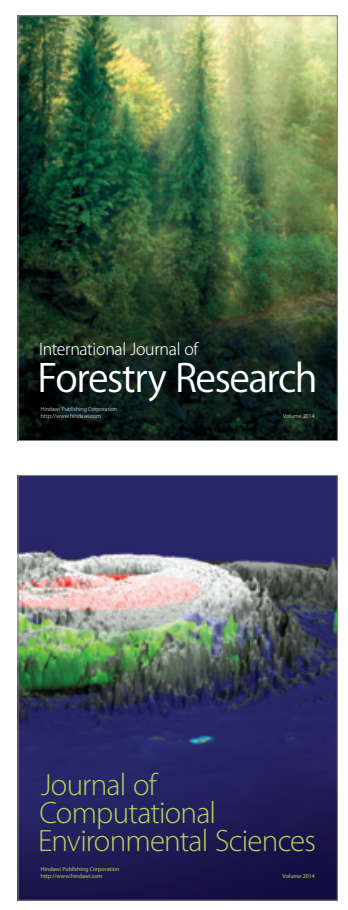
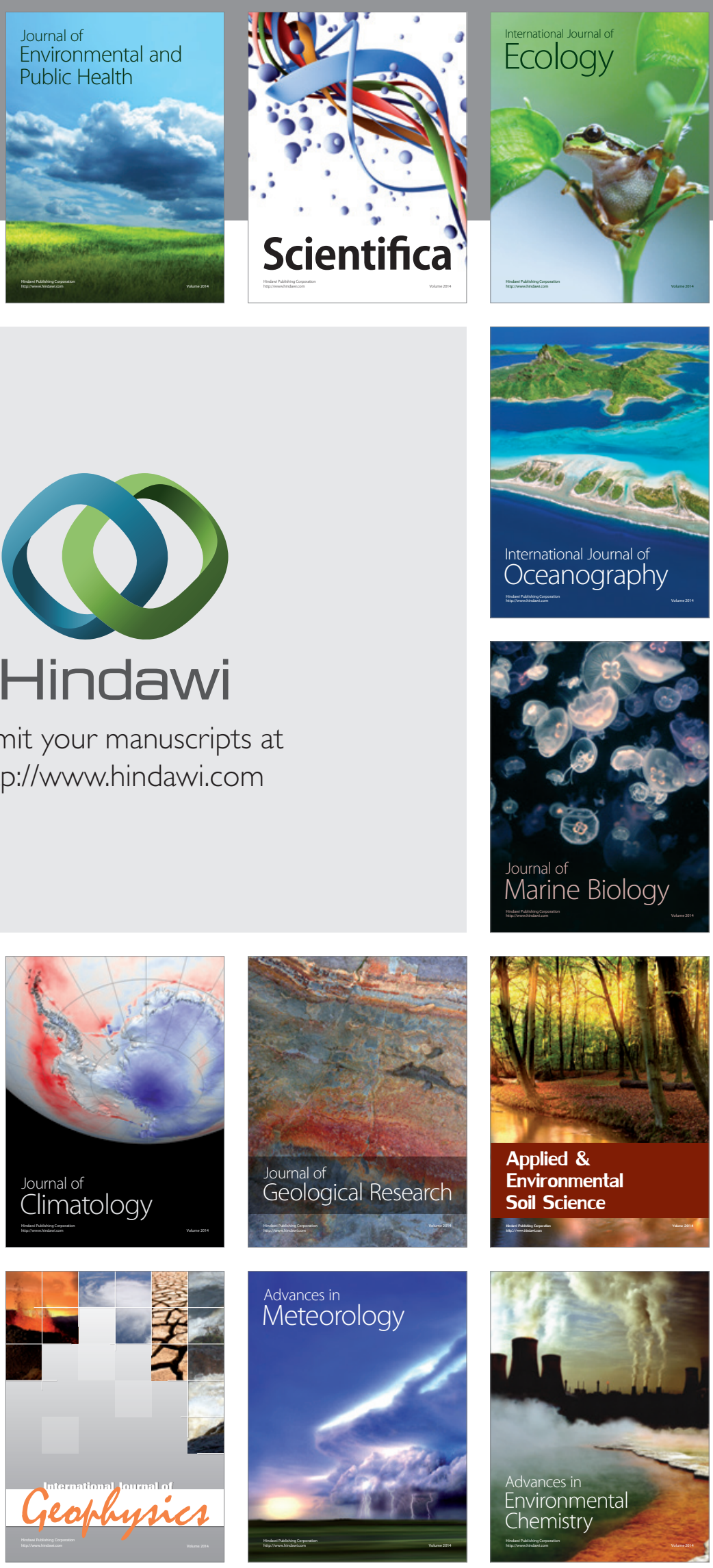